\title{
Shifts in Online Consumer Behavior: A Preliminary Investigation of the Net Generation
}

\section{Donghyun $\mathrm{Kim}^{1}$ and Anthony P. Ammeter ${ }^{2}$}

\author{
${ }^{1}$ Delta State University, College of Business, Mississippi, USA, dkim@deltastate.edu \\ 2 University of Mississippi, School of Business Administration, Mississippi, USA, tammeter@olemiss.edu
}

Received 3 October 2016; received in revised form 2 May 2017; accepted 11 July 2017

\begin{abstract}
The main purpose of this study is to examine the factors affecting the online shopping behavior of Netgeneration comparing with pre Net-generation. To do so, the research develops a research model including nine independent variables that are hypothesized to predict the intention of purchase using the online shopping context and Net-geners' characteristics. The partial least squares method of structural equation modeling was used to analyze 293 Net-geners and 246 preNet-geners. The results of the study show that the six online purchase determinants (product variety, feedback, responsiveness, personalization, acceptance of complaints, and enjoyment) are more important for Net-geners than for preNet-geners. This study contributes to the understanding of online purchasing behavior of the Net generation (Net-geners) and will help to envision new strategies for marketing to Net-geners.
\end{abstract}

Previous research has focused on shifts in technology and overlooks the shift of consumer demographics as the Net-geners are the first to grow up surrounded by digital media and the Internet.

Keywords: E-commerce, Net-generation, Online shopping behavior, PreNet-generation, Generational differences 


\section{Introduction}

The continuous growth of consumer retailing over the Internet has drawn considerable attention to electronic commerce (e-commerce). According to the U.S. Census Bureau, e-commerce sales have increased by 214 percent from 2006 to 2015. U.S. retail e-commerce sales for 2015 totaled $\$ 341.7$ billion, an increase of 14.6 percent from the prior year. Retail e-commerce sales in the United States are projected to grow to 548 billion US dollars by 2019. A related phenomenon involves the Net generation (referred to hereafter as Net-geners) that has grown up during this time frame: this is the first generation to mature from adolescence surrounded by digital media and the Internet [99]. In this paper we argue that this generation perceives aspects of the Internet such as the online shopping mall differently from those born prior to this generation. We examine the research question: What factors affect the online purchasing behavior of Net-geners? We believe that shifts in factors affecting online consumer behavior in the Net generation, if they exist and if we can identify them, can help us design appropriate technology for this emerging class of consumers. Given the size of their cohort, Net-geners will grow to become a powerful buying group [73].

Accordingly, e-commerce has begun to be researched extensively, most commonly in these three distinct areas: perspectives of web design [13], [20], [52], [64], [98], price and products [30], [31], [96], and consumer behavior [7], [8], [14], [101]. Examples include looking at web site usability and design [77], studying the factors for intentions to purchase [28], unplanned purchases and intention to return [57], and the development of measures of factors that influence the success of online shopping [101].

Studies in the information systems discipline that specifically look at a consumer's behavior in the online environment have examined dynamic pricing [37], the investigation of relative advantage of e-commerce based on the innovation diffusion theory [17], and the negative effect of product uncertainty and retailer visibility on customer satisfaction [64]. In addition, a review of relevant prior research has suggested that online shopping experience [51], trust, reputation, and website quality [87], and cognitive evaluations, attitudes, and behavioral factors [16] have the positive impact on online purchase intention. Moreover, the theories have extended through the study of gender difference in online trust [89], the impact of socio-economic status on behavioral intention and actual behavior [40], the examination of online purchase intention through a technology-oriented and a trust-oriented perspective [105], and the empirical study of online community self-disclosure using social exchange theory and social penetration theory [84].

While online consumer behavior has been the subject of considerable research in the last few years, limited scholarly attention has been devoted to understanding consumers and empirically validating a research model that investigates the potential differences in the factors that influence online purchase behavior among the different consumer generations. Most studies have investigated factors affecting online consumer behavior without considering that variability often exists among online consumers in terms of their a priori preferences/attitude regarding a technology. Further, prior studies may have provided limited insight into the turbulence of ICT because they occurred prior to a shift in online consumer demographics. From the end of 1990 to early 2010, research on consumer behavior in ecommerce was frequently conducted. For these studies, target subjects were born before 1980 . The online market was a new innovation for them so they were less familiar with online shopping. However, the Net generation is the first generation to grow up surrounded by digital media and the Internet [99] and perceives the online shopping mall as another part of their environment because they were born using computers and the Internet. Drawing on previous research [45], [50], [56], [74], [93], [99], we believe that the existing factors affecting online purchase decisions of preNet generations (referred to hereafter as preNet-geners) will be different from the factors for Net-geners. For example, for preNet-geners, security is one of the most important factors in making an online purchasing decision [97]. On the other hand, for Net-geners, responsiveness of online sellers will be thought to be a more important factor than security because they trust online shopping as much as offline shopping, are starving for information, and want to communicate [56], [114]. Given the discussion to this point, an important question is whether the previously researched factors can predict the behaviors of Net-geners. Thus, the current study focuses on revealing differences in online behavior between a set of newly emerging consumers versus traditional consumers. Online shopping will have to face the new realities of Net-geners' culture and values, and what they want from online shopping.

Information systems research has made significant strides toward understanding the antecedents of IT use such as the technology acceptance model [21], [22], [107], the unified theory of acceptance and use of technology [9], [108], [109], and the innovation diffusion theory [5], [15], [62]. Understanding individual acceptance and use of information technology is also one of the most mature streams of information systems research [6], [106]. However, these theories and models predict IT adoption/use have lacked the understanding of users. Most studies have looked at which factors affecting subsequent user attitudes, beliefs, and intentions, considering all users share the same culture, beliefs, and values [21], [63], [109]. Thus, the studies are limited in their ability to offer specific silent factors affecting the different user generations' IT adoption/use behavior. Usage of information systems is complex and multifaceted. Research that can situate the understanding of IT users a body of theory and produce evidence to help IT managers and researchers understand the differences in online behavior between a set of newly emerging users versus traditional users is thus likely to advance both research and practice. In the next section, we define the Net-generation (Net-geners) to understand its characteristics and factors that predict online purchase behavior. Following that, we review previous research concerning online consumer behavior from 1990 to 2000 to determine the influential factors on Net-geners and establish a model to examine the factors affecting their behavior in online shopping. Next, we test our model using 
Net-geners and previous Net-generation (preNet-geners). Finally, we derive managerial and research implications from the results of this study.

\section{Literature Review}

It is important to define the Net-generation as distinguished from prior generations of online purchasers. We report on research detailing the characteristics of this generation in order to inform the theoretical development of our research model.

\subsection{Pre-Net Generation}

A generation exists across the world, in all kinds of economic and social conditions. One of the generational changes is the rise of the Internet, computer, and other digital technologies [99]. Drawn on this, Prensky (2001) defines two generations based largely on age and technological experience: digital immigrant (preNet-geners) and digital natives (Net-geners) [85]. Oblinger and Oblinger (2005) categories generations as distinct groups that fall into the Mature (1900-1946), Boomers (1946-1964), Generation X (1965-1982), and Net Generation/Millennials (1982- present) [74]. PreNet-geners, who were born before the Internet and personal computers, learn from formal classroom instruction. Their learning is textual and verbal, formal, linear, and deductive [85]. PreNet-geners have experienced a pre-digital world and grow up without technology such as the Internet and personal computer. While Net-geners grow up with technology and understand it as a part of daily life, preNet-geners view technology as an innovation and grew up in an analogue world [27]. Thus, preNet-geners need to learn to adapt to the new digital environment and preNet-geners are less adept with and confident about using digital technologies than Net-geners [91]. In everyday life both generations use many of the same technologies (mobile phone, tablets, Web 2.0, etc), but the types of activities they are undertaking and the concerns they have are very different [50]. PreNet-geners' frequency of using technologies such as word processing, spreadsheet, presentation, and Web search engines is higher than Net-geners while Netgeners engage with more games, social networking and video blogging with their mobile devices than preNet-geners [91], [111].

\subsection{The Net Generation}

The Net-generation (Net-geners) is the first generation to grow up surrounded by digital media and the Internet. Tapscott (2008) describes Net-geners as the 88 million offspring of 85 million baby-boomer adults in the United States and Canada and starts this generation in January 1977 and ends it in December 1997 [99]. Oblinger and Oblinger's (2005) suggest that Net-geners were born in or after 1982 and that it ends in 1991 [74]. We define Net-geners as the generation born after 1980. Our definition differs from Tapscott's (2008) The Echo Boomers and Oblinger and Oblinger's (2005) Millenials. Our approach has recognized that age is not the sole determinant but the level of exposure to technology should be considered as a determinant [74]. Oblinger and Oblinger (2005) suggest exposure to technology might be more important than age group. Microcomputers, small, low-cost computers that could be owned by individuals and small businesses, became ubiquitous in the 1980s, the first $1 \mathrm{G}$ network and hand-held mobile phones were introduced in 1983, and the Internet funding of a new U.S. backbone by the National Science Foundation in the 1980s led to worldwide participation and expanded the Internet for popular use in the 1990s.

Since birth, the Internet and e-commerce have been second nature to them. Twenty percent began using computers between the ages of five and eight and all Net-geners were using computers by ages of 16 and 18 [74]. Thus, for Netgeners, digital technology is no more intimidating than a DVD player or toaster [99]. Oblinger and Oblinger's (2005) study of how Net-geners define technology shows that they consider Web-browsing, and Internet constitute technology as neutral and common technology [74]. Thus, e-commerce is an easy and normal shopping channel. Common items they purchase are CD's, books, clothes, shoes, and computer and video games. Also, the majority of Net-geners use the Internet as a preferred source of shopping, supporting the notion that the Internet is most commonly used for window shopping [100]. Not only are Net-geners familiar with e-commerce and digital technology, but they are also more populous than the baby-boomer generation. They are also better trained for using the Internet and digital devices than any previous generation. Due to their ability to control digital media and their numbers, they are believed to be destined to shake up current business practices and have a great effect on the corporate world.

As reviewed in Table 1, Net-geners are distinguished from preNet-geners in terms of their unique characteristics: (1) technology savvy, (2) refinability, (3) sense of entitlement, (4) social, (5) scrutiny, (6) global orientation, (7) multitasking, (8) free expression, (9) immediate, and (10) regulation. First, Net-geners are able to understand and want to control technology [44], [45]. As Net-geners have grown up with widespread digital technology, they are more open to the newest innovations than the previous generation. Thus, they intuitively and inherently absorb abilities to use IT devices and to navigate the Internet. This leads Net-geners to be equipped with high levels of skill to understand and deal with technology. Moreover, beyond the acceptance of technology, Net-geners want to control technology. They are willing to be activists in the digital environment. Second, with given the technology expertise and growing up with the media rich environment, Net-geners have easy access to massive amounts of information and quickly understand and organize them [27], [114]. Third, Net-geners expect companies display honesty [27]. They believe that access to information and the expression of opinions are fundamental rights [74], [99]. Stewart (2009) described a sense of 
entitlement held by Net-geners who often challenge tasks, results, and evaluations. Fourth, Sixth, Net-geners are socially and emotionally open to sharing with strangers they meet on the online [56], [99]. The social nature of Netgeners implies that interactivity is an important characteristic, as Net-geners seek to interact with others and often crave interactivity. Fifth, Net-geners instinctively scrutinize any information they encounter [26], [32], [56]. They expose hoaxes quickly, and make short work for false pretense. Sixth, with a great ability to utilize the technology such as the Internet, Net-geners communicate with others around the world [56], [65]. Seventh, with a variety of information communication technologies such as TVs, computers, phones, and instant messaging as integral part of their lives, Net-geners have become master of multitasking [74], [99], [114]. Eighth, Net-geners are emotionally uninhibited and easily express their inner thoughts and feelings [114]. Ninth, the digitally literate and interactive nature aligns with their need for "immediacy" [56], [114]. Net-geners are able to respond quickly and expect rapid responses in return. Finally, Net-geners have grown up in a sheltered environment with the steady of support of protective parents concerned about their safety, success, and future [65]. Net-geners' parents are supportive forces in their children's education [39]. This leads that they are hardworking and have been socialized by supportive parents to be successful in life [26]. The hectic lifestyle have accustomed Net-geners to structure time, work from schedules and following rules [39].

Table 1: Characteristics of net generation

\begin{tabular}{|c|c|c|c|c|c|c|c|c|c|c|c|c|c|c|c|c|}
\hline Characteristics & 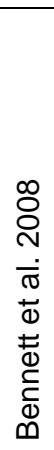 & $\begin{array}{l}N \\
\delta \\
\text { r } \\
0 \\
\frac{0}{U}\end{array}$ & 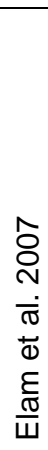 & 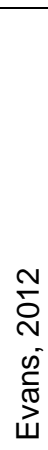 & 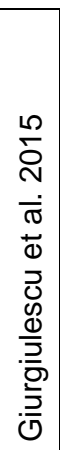 & 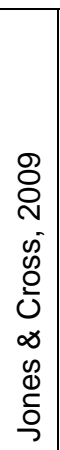 & 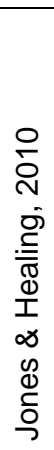 & 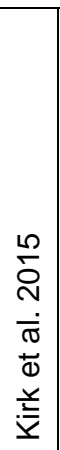 & 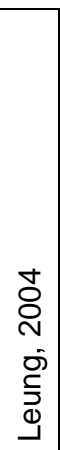 & 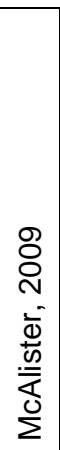 & 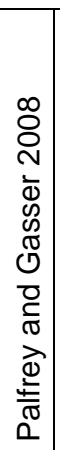 & 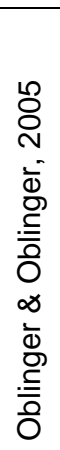 & 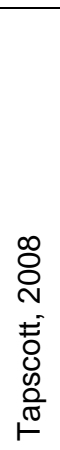 & 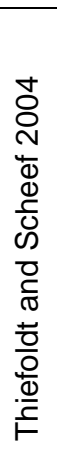 & 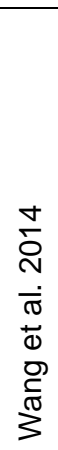 & 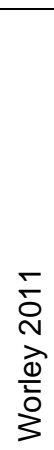 \\
\hline Technology Savvy & $\mathrm{X}$ & $\mathrm{X}$ & $\mathrm{X}$ & $\mathrm{X}$ & $\mathrm{X}$ & $\mathrm{X}$ & $\mathrm{X}$ & $\mathrm{X}$ & $\mathrm{X}$ & $\mathrm{X}$ & $\mathrm{X}$ & $\mathrm{X}$ & $\mathrm{X}$ & $\mathrm{X}$ & $\mathrm{X}$ & $\mathrm{X}$ \\
\hline Refinability & $\mathrm{X}$ & $\mathrm{X}$ & $\mathrm{X}$ & $\mathrm{X}$ & & $\mathrm{X}$ & $\mathrm{X}$ & $\mathrm{X}$ & $\mathrm{X}$ & & $\mathrm{X}$ & $\mathrm{X}$ & $\mathrm{X}$ & & $\mathrm{X}$ & $\mathrm{X}$ \\
\hline Sense of entitlement & & $X$ & $X$ & $\mathrm{X}$ & & & & & $X$ & $\mathrm{X}$ & $X$ & $X$ & $X$ & $\mathrm{X}$ & & $\mathrm{X}$ \\
\hline Social & $\mathrm{X}$ & $X$ & $X$ & $X$ & $\mathrm{X}$ & $\mathrm{X}$ & & $\mathrm{X}$ & $X$ & $X$ & $X$ & $X$ & $X$ & $X$ & & $\mathrm{X}$ \\
\hline Scrutiny & $\mathrm{X}$ & & $\mathrm{X}$ & $\mathrm{X}$ & $\mathrm{X}$ & & & $\mathrm{X}$ & $\mathrm{X}$ & & $\mathrm{X}$ & $\mathrm{X}$ & $\mathrm{X}$ & $\mathrm{X}$ & & $x$ \\
\hline Global orientation & & & & & $\mathrm{X}$ & & & & $\mathrm{X}$ & & $\mathrm{X}$ & $\mathrm{X}$ & $\mathrm{X}$ & & & $\mathrm{X}$ \\
\hline Multitasking & $\mathrm{X}$ & $\mathrm{X}$ & $\mathrm{X}$ & $\mathrm{X}$ & $X$ & & $\mathrm{X}$ & & $X$ & $\mathrm{X}$ & $X$ & $X$ & $X$ & & $\mathrm{X}$ & $\mathrm{X}$ \\
\hline Free expression & & & $X$ & $X$ & & & & $\mathrm{X}$ & $X$ & & $X$ & $X$ & $X$ & $\mathrm{X}$ & & $\mathrm{X}$ \\
\hline Immediate & $\mathrm{X}$ & $\mathrm{X}$ & $x$ & & $\mathrm{X}$ & & $\mathrm{X}$ & $X$ & $X$ & & $X$ & $X$ & $\mathrm{X}$ & & & $x$ \\
\hline Regulation & $\mathrm{X}$ & $X$ & $X$ & & $X$ & & & & $X$ & $X$ & $X$ & $X$ & $X$ & $\mathrm{X}$ & & $x$ \\
\hline
\end{tabular}

\subsection{Consumer Expertise}

Net-geners possess plenty of experience about online shopping. In a study on consumer knowledge, Alba and Hutchinson (1987) describe consumer expertise as "the ability to perform product-related tasks successfully" [1] p. 411. In addition, they explain familiarity as "the number of product-related experiences that have been accumulated by the consumer" [1] p. 411. Expertise and familiarity are the major components of consumer knowledge. Thus, Net-geners can be considered knowledgeable consumers and experts about online shopping because they have been exposed to online shopping almost their entire lives and can easily use the Internet in order to navigate and find what they want.

Unlike novices, experts have several distinct purchasing behaviors. First, expert consumers tend to use more information than novices during the purchasing decision-making process. Brucks (1985) and Moorthy et al. (1997) demonstrate that the relationship between consumer knowledge and total amount of information search is positively correlated, up to a certain point [10], [71]. But, after this point, the relationship changes to negative because of less efficient searching. Experts have the ability to analyze, elaborate, and make more accurate inferences from information [1], [71]. Also, the refined and complete cognitive structures for analytic processing enable experts to search relevant information and ignore irrelevant information [1], [86]. Brucks (1985) argues that experts avoid inappropriate information and are more likely to find relevant and accurate information [10]. Last, experts are inclined to ask more questions than novices in complicated situations, using more effective ways of asking in order to derive information [70]. In addition, online shopping experience has positive mediated effects through satisfaction and repurchases intention [51]. Finally, we believe that consumer expertise in online shopping is a key driver of the impact of the differences in online shopping behavior between Net-geners and preNet-geners. 


\section{Theory Development and Research Model}

Our research model incorporates four phases of the Internet business transaction process as detailed by Selz and Schubert (1997) [92]. The Web Assessment Method (WAM) identifies information, agreement, settlement, and aftersales interactions (community) phase as the four components that can impact online purchase decisions. We therefore drawn upon this work as a basis for categorizing the factors that we identify as potentially contributing to e-commerce research and extend it by suggesting that sources of e-commerce inertia can similarly arise from the four the WAM components. The factors that we consider for these phases are detailed in Figure 1. In the information phase, information abundance and product variety detail how customers collect information about products to reduce the uncertainty of purchasing a product [53], [115]. In the agreement phase, we explore interactions between sellers and buyers by looking at the impact of feedback and responsiveness on online purchase behavior [78], [95]. In the settlement phase, ease of return and acceptance of complaints describe delivery of the ordered products and aftersales interactions occur [64], [52], [103] while the environment phase looks at the overall transaction process summarized by enjoyment and purchase involvement. Consistent with past research in online shopping and ecommerce [30], [55], [69], [92], [110], [112], the behavioral intention construct (online purchase intention) assess a subject's likelihood to use a website to purchase a product(s). Here, we have chosen to use behavioral intention as a surrogate for actual behavior. The following section discusses each of these in depth and hypotheses are developed for each factor.

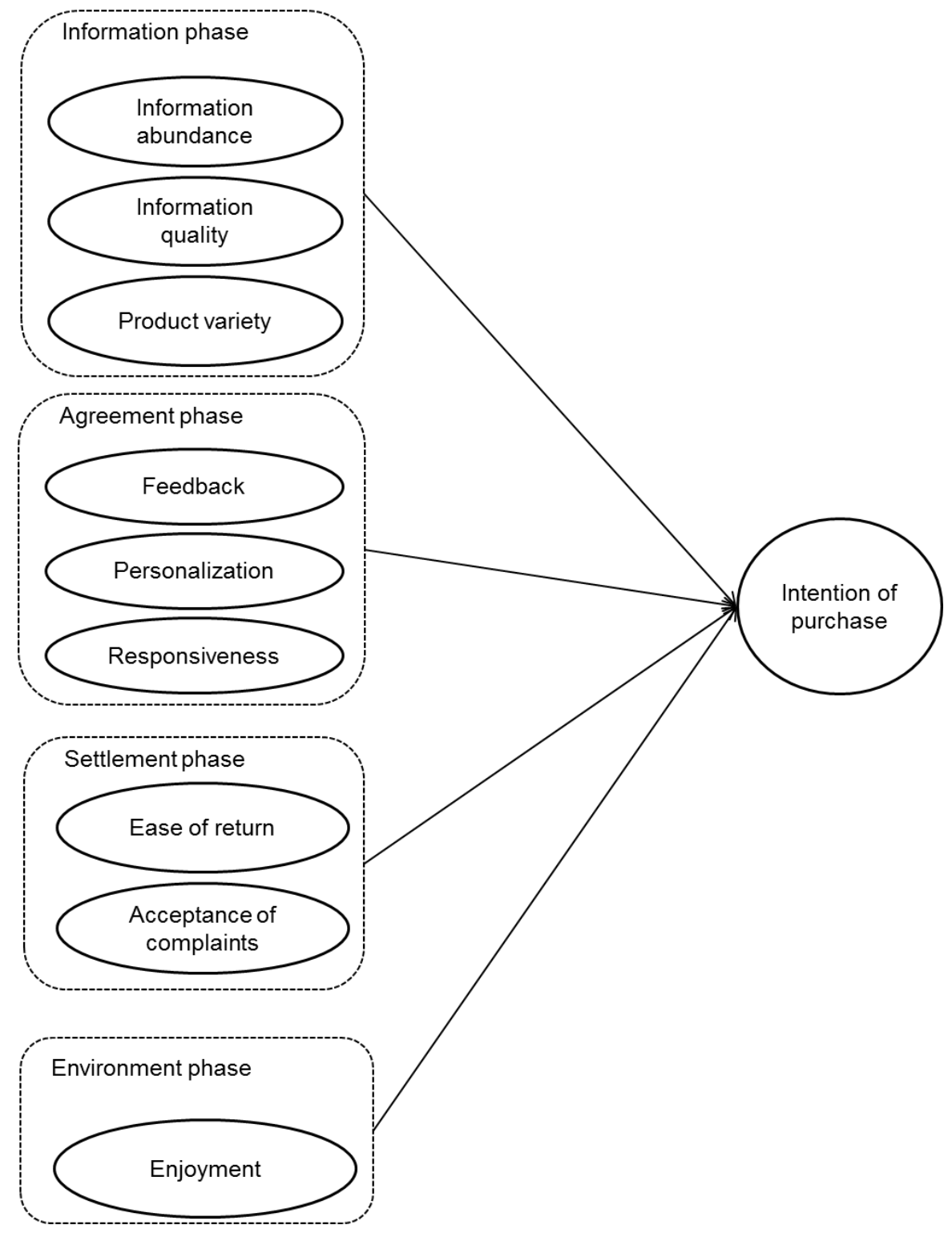

Figure 1: Research model 


\subsection{Information Phase}

Product Variety. In the current research, product variety refers to the extent to which online customers have a broad choice of available products from the online shopping mall. The value of e-commerce to customers is driven in part by the large amounts of product information and product variety available in online shopping [49]. A wide selection of products leads to better comparison shopping, eventually more purchases [49], and positively affects online consumers' perceptions [16]. In addition, a wide product variety increases customer welfare 7 to 10 times more than the customer welfare gained from lower prices [11]. Net-geners desire to have a wide selection because they live with a tremendous amount of options, TV channels, and Internet sources. In addition, Net-geners are demanding regarding the need for options as confident consumers [27]. This leads to our first hypothesis.

\section{H1: Product variety will positively affect Net-geners' online purchase intentions.}

Unlike Net-geners, preNet-geners undertake online shopping primarily in order to save shopping time and effort. Torkzadeh and Dhillion (2002) demonstrate that for preNet-geners, shopping convenience is more important than a variety of product choice in online shopping [102]. McLellon and Schiffman (2002) argue that seniors (50 +) view the Internet and computers as new phenomena or forces that better their lives. Their major activities on the Internet are emailing and surfing in order to complete an activity or task. Minor activities are entertainment, chatting, window shopping, and paying bills. This implies seniors' Internet behavior pursues efficiency rather than effectiveness.

In addition to the different online purchase behavior derived from the age variation, for preNet-geners unaccustomed to surfing through numerous options, a wide set of choices could be a drawback and hinder their primary reason for using online shopping. However, Net-geners have easy access to vast amounts of information and they quickly absorb and organize acquired information [65]. High level of technology exposure such as playing video games has made Net-geners quick thinkers who can react in a moment's choice [26]. Given their sophisticated and inherent comparing ability [99], Net-geners are accustomed to surfing a wide set of choices [61].

H1-1: Product variety will have a stronger effect on online purchase intention for Net-geners than for preNet-geners.

Information abundance. Information abundance refers to the extent to which customers acquire available information. Information acquisition in the online shopping environment is often limited to observing a picture of the product. Thus, consumers place high value on information concerning a product [92]. Dholakia and Rego (1998) empirically demonstrate a positive relationship between providing image information and the daily hit-rates on an online shopping site [25]. In addition, Qureshi et al (2009) investigate a positive effect of web site quality such as information on repurchasing intention [87]. Thus, abundant information is important for Net-geners in order to assess products and make purchase decisions.

\section{H2: Information abundance will positively affect Net-geners' online purchase intentions.}

In response to the proliferation of information brought about by advances in communications and information technology, the amount of time and effort required to sort through and process this information has increased. Netgeners, however, possess high levels of ability to collect and manage information, thus making it easy to navigate such a wealth of information. The process to search and use valuable information for making purchase decisions in online environments doesn't appear to have a cost to Net-geners, who frequently utilize the Internet as a tool for window shopping and product comparison [100]. In other words, given the nature of the ability to search information, Netgeners are able to find more information with lower cost [1], [10] and use more information in the complicated processes of comparing products or brands [71].

PreNet-geners have relatively lower ability to refine excess information than Net-geners. As people get older, they depend more on an immediacy reading strategy, a dynamic reading system that processes new information as it is encountered, than a buffering reading strategywhich reserves final analysis (interpretation (or integration) of new information with other information given) until the ends of significant syntactic constituents, because of poor memory. Theories of age-related processing deficits suggest that an older reader will accept fewer new concepts (or information) due to poor memory regarding the content. That is, they will allocate less time to process a new concept (or information) because the age deficit in memory for discourse declines in more basic information processing. In addition, the greater the information load of the sentence, the less they allocate time to process new information because of the greater demand of integration. Finally, younger people (18-30) are more likely to spend more time and effort in order to process new information than older people (58-76). In other words, understanding excess information causes more searching cost of preNet-geners than of Net-geners. High search cost can attenuate the benefit of online shopping. Thus, abundance of information positively affects the intention to purchase of Net-geners more than it affects the intention to purchase of preNet-geners.

H2-1: Information abundance will have a stronger effect on online purchase intention for Net-geners than for preNetgeners. 


\subsection{Agreement Phase: Interactivity}

Given the timeless and spaceless nature of Internet communication, e-commerce allows a company to interact with customers continuously. For Net-geners, online interaction is a part of life, and online interaction is a common inherently acquired habit. Interactivity in the context of online shopping is defined as the degree to which a customer can communicate with sellers and control the content of an interaction in order to solve curiosity and problems [100]. Interactivity has three dimensions: feedback, responsiveness, and personalization.

Feedback. Feedback has emerged as a viable mechanism that offers information from the perspective of consumers [31]. Feedback mechanism is which allows buyers to report his/her satisfaction with the transaction to a central authority [30]. In this research, Feedback refers to the extent to which customers receive/provide information and experiences about product and service from/to others. By making feedback public, participation by providing product referrals bestows customers much influence over potential sales [79]. Prior studies suggest that consumer review mechanism also positively influences trusting beliefs, perceived usefulness, and perceived affective quality for experience goods [7], customer reviews have the positive impact on less-known product sales [23], the overall average product rating in social shopping communities is positively associated with online purchase [2], [30], [75], and information generated by real users enhances the knowledge about a product and facilitates users to make better decisions [7]. In addition, the comments of a community could change a consumer's preference [18]. This plays a prime role during the purchase decision stage.

\section{H3: Feedback will positively affect Net-geners' online purchase intentions.}

Net-geners' ability to access to immediate information through communication technologies has taught them to expect immediate answers and feedback [114]. Moreover, Net-geners like to communicate, argue, and debate with others. Net-geners are highly demanding 24/7 lifestyle driven by the Internet and mobile technology [27]. Jones et al. (2010) have found that Net-geners are active users and that in general they use technologies more than they believe that they are required to [46]. More than $80 \%$ of the respondents have reported that they use technology to keep in touch with other students and family [44]. Constant communication offers Net-geners with interpersonal skills [46], [111]. Thus, they can instantly comment on any information they find and are constantly making comments [99]. This inherent communication habit distinguishes them from preNet-geners and Net-geners are continuously eager to communicate with others in the virtual world. Therefore, Net-geners are more likely to depend on feedback than preNet-geners do.

\section{H3-1: Feedback will have a stronger effect on online purchase intention for Net-geners than for preNet-geners.}

Responsiveness. One of the most important aspects of online shopping is bidirectional communication capability. In the brick and mortar shopping mall, consumers and sellers have limited time to communicate because they must be in the same place at the same time [88]. Unlike offline customers, online consumers are allowed to communicate with sellers via a variety of ways such as e-mail and bulletin boards [104]. Thus, in the online setting, being able to access desired information quickly offers users an advantage over less-interactive online shopping malls by permitting users to make a purchase decision [56]. In addition, the perceived willingness of responding to customer needs and problem solving, along with response speed, affects consumers' attitudes toward online shopping [94]. Jahng et al (2007) empirically demonstrate the positive effect of the richness of consumers' interaction with products and with sales representatives on their attitude towards electronic commerce [42]. Thus, we defined responsiveness as the degree to which online sellers respond to customer inquiry and how the customers perceive the willingness of the online shopping mall to satisfy them. It is important for customers to have responses about inquiries and solve problems that happened during transactions with the online shopping mall [18]. Given the social, interactive and immediate nature of Net-geners [74], responsiveness which is an important aspect affecting purchase intention will attract Net-geners.

\section{H4: Responsiveness will positively affect Net-geners' online purchase intentions.}

As discussed above, Net-geners, as experts of online shopping, are willing to ask more questions about products or brands than novices do [70]. Net-geners want inquiry-based approaches to learning because it is important for Netgeners to know. The active information searching behavior via digital communication methods is one of the unique natures of Net-geners as experts [56]. This behavior is accelerated by diverse and effective communication channels between sellers and buyers in the online environment because the digital communication technologies such as computers, smartphones and so on are primary mediators of human-to-human connections [69], [76]. Not only do Netgeners review information already posted in an online shopping mall, but they also request information which has not been provided but they want to know.

The digital technologies experience and expertise level influence the effects of digital communication ability [54]. Users with less experience and expertise may find interaction with online sellers to be too complex. This decreases pleasure but increase arousal and high levels of arousal can over-stimulating, which can cause users to reject digital media [29]. Net-geners generally have more experience and expertise with the Internet and digital devices than preNet-geners do. Thus, unlike preNet-geners, Net-geners do not hesitate to communicate with sellers in order to have rights to know 
what they want to know. Finally, we suggest that responsiveness is more important to more important to Net-geners than to preNet-geners.

\section{H4-1: Responsiveness will have a stronger effect on online purchase intention for Net-geners than for preNet-geners.}

Personalization. Final dimension of interactivity is user control, which can be interpreted as personalization in the online environment, in terms that controlling a web site involves a user customizing the web site to his or her liking [8]. Advanced information technologies such as collaborative filtering, data mining, and click-stream analysis empower online shopping to provide customer-tailored shopping experiences. Used properly, personalization allows online shopping malls to better understand and satisfy their customers' needs. Prior studies related to web personalization are divided into two main streams. The first stream includes studies on the applications of personalization. These studies highlight new applications of personalization technology and their commercial potential [98]. The second stream has focused on technologies for tracking online customers, inferring customer preferences, purchasing behavior, and offering a set of personalized product recommendations or presenting customized interfaces [8], [58], [72], [96], [116]. Customized interfaces include presenting products customers have searched for before and/or are related to the products customers previously purchased. The current study focuses on this second research stream: delivery personalization and defines as personalization in the context of online shopping is the degree to which customers receive product and service recommendations customized to receivers' needs. Shergill and Chen (2005) suggest that personalization is a key factor of online shopping mall design and that personalization is positively associated with frequent online customers more than with trial online customers [94]. Net-geners want to take control of their working environment, as the emphasis of Net-geners is not placed on information acceptance but on information control [61]. In online shopping, perceived behavioral control is recognized as "the consumer's perceived ease or difficulty of getting product information from a vendor's website..." [81] p. 119. Providing personalized information enables customers to easily find what they need [116]. This results in online customers enjoying high levels of control [57]. Therefore, given the information-controlling nature of Net-geners, we expect that Net-geners prefer to buy something from an online shopping mall that provides personalized information to one that doesn't.

\section{H5: Personalization will positively affect Net-geners' online purchase intentions.}

For preNet-geners, exposing personal information has been considered a nuisance of online shopping. Thus, from the beginning of online shopping research, security has been highlighted as a solution to protect the loss of personal information [49]. Jarvenpaa and Todd (1996-1997) suggest that online customers perceive personal risk that includes the loss of personal information when they customize their web sites [41]. Personal risk will have a greater effect on the online behavior of preNet-geners. Thus, preNet-geners are less likely to customize online shopping because they prefer not to reveal their personal information. On the contrary, given the nature of the control over technology and uninhibited expression they have in the online environment, Net-geners are more likely to give more weight to personalization over security than will preNet-geners [61].

\section{H5-1: Personalization will have a stronger effect on online purchase intention for Net-geners than for preNet-geners.}

\subsection{Settlement Phase: Rights and Post Purchase Service}

Acceptance of complaints. Post-purchase service is a vital factor affecting online consumer behavior and influencing retention of purchases [18], [51]. Post-purchase service includes two dimensions: acceptance of complaints and ease of return and exchange.

Net-geners have grown up with steady support of protective parents concerned about their safety, their schooling and their academic and extracurricular success [19], [26]. This has instilled in Net-geners a number of positive characteristics. They are hardworking and have been socialized by supportive parents to be successful in life. Thus, they are confident and like to help others and address social problems. In addition, growing up in this cultural environment has accustomed them to structuring their lives, working from rules and following rules [59]. Along with this structured lifestyle is the expectation that they refer to being assessed by some form of standardized testing and receiving focused feedback [19], [26]. Second, with the integration of their lifestyle and their access to and use of technologies, they have a tendency to express themselves and relate to one another in ways mediated by digital technologies [38]. Adapted to communicate with others around the world, Net-geners easily express their thoughts online [61]. Also, Net-geners are becoming a generation of critical thinkers because they have been trained to express opinions, debate, and protest via the Internet [99]. In the online settings, complaints from mismatching and unmet expectations frequently occur, due to the disembodied nature of the online environment. In the current study, acceptance of complaints is defined as the extent to which sellers accept and react to customers' complaints. We assume Net-geners do not hesitate to raise complaints regarding these issues and want sellers to accept their complaints according to rules.

\section{H6: Acceptance of complaints will positively affect Net-geners' online purchase intentions.}

On the other hand, preNet-geners are not accustomed to complaining asynchronously [43]. PreNet-geners prefer synchronous communication and are less likely to send in a complaint to a web site and wait for a response because they may find the complexity of asynchronous communication overwhelming [56]. In addition, PreNet-geners are less 
likely to reveal their personal information because preNet-geners are more fearful than Net-geners of the negative implications of sharing personally identifiable information online [43]. Moreover, constant communication through digital devices provides Net-geners with interpersonal skills that work well in online purchase process [65]. Altogether, we suggest Net-geners will put more importance on the online sellers' ability of accepting their complaints than preNetgeners.

H6-1: Acceptance of complaints will have a stronger effect on online purchase intention for Net-geners than for preNetgeners.

Ease of return and exchange. A complex return policy can be a reason for a customer to abort online purchases [17]. On the other hands, a lenient return policy is positively associated with order frequency [69] and ease of return is one of the significant factors affecting the willingness of customers to shop again in the same online shopping website [88]. Khalifa and Liu (2007) empirically examine the positive effects of after-sale service, transaction efficiency, and convenience on perceived online shopping usefulness [51]. With a strong belief in equal opportunity, Net-geners are likely to pursue their rights even after purchase. They would not accept a product that differs from what they expect and Net-geners are not afraid to return purchases. Thus, an easy return policy will affect Net-geners' intention to purchase.

\section{H7: Ease of return and exchange will positively affect Net-geners' online purchase intentions.}

Recent evidence suggests that Net-geners pursue their rights and have strong beliefs in equal opportunity [74]. These rights include not being disadvantaged when online shopping is compared to traditional shopping [61]. Therefore, with a strong sense of entitlement, Net-geners are more likely to return and exchange products that are defective or mismatching with description on website. Considering that growing up in the structured lifestyle has accustomed Netgeners to working from rules and following rules [26], [59], the current research thus hypothesized:

H7-1: Ease of return and exchange will have a stronger effect on online purchase intention for Net-geners than for preNet-geners.

\subsection{Environment Phase}

Enjoyment and purchase involvement, as factors of the environment phase, affect all phases of online shopping transactions. In other words, the environment phase makes customer stay in other transaction processes.

Enjoyment. For some, shopping is not simply a process to acquire goods in modern life. Shopping can also be a source of enjoyment. Enjoyment refers to the extent to which customers feel fun, interest, and excitement during shopping. The level of intrinsic enjoyment of the shopping experience affects consumer behavior such as the intention of return and purchase intention [41], [69]. In addition, enjoyment as a pleasure emotion to previous transactions with the online shopping influences a user's perceived value of online shopping and purchase intention [14], [30]. To examine Netgeners' characteristics, Park and Lee (2005) compared the shopping behavior of five clusters divided by age and Internet experience [80]. They found that Net-geners use online shopping not only to purchase but also for enjoyment. Thus, enjoyment will have a positive impact on Net-geners' online purchase intentions.

\section{H8: Enjoyment will positively affect Net-geners' online purchase intentions.}

According to McMellon \& Schiffman (2002), seniors $(50+)$ are utilitarian because their major activities are e-mailing and surfing (information searching), and their minor activities are entertainment, chatting, window shopping, and paying bill [68]. Utilitarian is task-oriented, efficient, and rational and tends to minimize search cost, while the hedonic group is looking for fun, joy, and enjoyment through online shopping. In addition, McMellon \& Schiffman (2000) present that seniors allocate more time to emailing (necessary tasks) than any other Internet behavior (personal communication, financial matters, reading messages, window shopping, searching for information, and entertainment) [67]. The more an individual has to do necessary tasks on the Internet, the less time they will allocate to more leisurely activities. In addition, Phang et al (2010) reveal that older shoppers are more likely to prefer search and deliberation shopping strategy over hedonic browsing than younger shoppers [83]. This implies that preNet-geners' Internet behavior pursues more necessary tasks than leisurely activities. In other words, the Internet is a tool which aids preNet-geners to do communication tasks, not a tool that gives them enjoyment. McMellon et al (1997) investigate senior's Internet behavior [66]. The research classifies the seniors into two groups in terms of attitude toward technology. Technology lovers have long time exposure to electronics. They view the impact of computers and online services on their lives more positively. They believe that they are innovators and more in control of their lives and purchase more products via online and perform a greater variety of online activities, such as online social activities and searching information. However, unlike Net-geners, technology lovers even consider the Internet and computers as new technology and complex tools which are used for solving problems. They regard the Internet and computers as intellectual pursuits. This attitude is different from Net-geners', with which they consider the Internet and computers commodities. They don't regard the Internet and computers as things to learn or acquire but as things to enjoy. Thus, we suggest another hypothesis.

H8-1: Enjoyment is more important to Net-geners than to preNet-geners. 
Purchase involvement. Purchase involvement is defined as the customer's perceived relevance with the focal purchase based on inherent needs and interests [81]. Prediction of behavior-induced purchase involvement should be examined by considering the meaning of involvement derived from differences in the antecedent conditions producing involvement [60]. Four dimensions have revealed in Laurent and Kapferer's study (1985): the perceived importance, the perceived risk associated with the product purchase, the sign, and the hedonic value. We adapted the perceived importance because the current study focuses on general online purchase behavior rather than purchase behavior for a specific product category.

Involvement with purchases leads customers to search for more information about products and spend more time on product diagnostics for the right selections [60]. Net-geners with the ability to search for information are more likely to make an important transaction from online because online shopping reduces their searching costs.

\section{H9: Purchase involvement will positively affect Net-geners' online purchase intentions.}

Unlike Net-geners, highly involved preNet-geners are less likely to make online purchases due to the relatively low refinability of excess information [56]. Even though the involved purchases require more information, preNet-geners won't spend a lot of time searching information online. On the other hand Net-geners are willing to make highly involved online purchase because they are accustomed to a wide variety of information and can absorb and organize that information quickly [48]. Therefore, the positive impacts of high involvement on intention of purchase in online are weaker for preNet-geners than Net-geners.

H9-1: Purchase involvement will have a stronger effect on online purchase intention for Net-geners than for preNetgeners.

\section{Research Methodology and Data Collection}

In this section we describe how we developed a survey instrument that incorporated prior research on online shopping and how we conducted two pretests to further refine this instrument. We then describe how we sampled Net-geners and preNet-geners and provide descriptive statistics for our sample.

\subsection{Measurement Items}

An initial structured questionnaire was developed based on a review of existing literature with modifications to fit the context of the current study. We have nine shopping factors as independent variables and one dependent variable (Table 2).

Table 2: Measurement Items

\begin{tabular}{|c|c|c|}
\hline \multirow[t]{5}{*}{$\begin{array}{l}\text { Personalization } \\
\text { (Tsai \& Huang, } \\
\text { 2007) }\end{array}$} & PER1 & $\begin{array}{l}\text { I prefer that an online shopping mall makes purchase recommendations based } \\
\text { on my shopping history in that online shopping mall, or based on my personal } \\
\text { information that I provided to that online shopping mall. }\end{array}$ \\
\hline & PER2 & $\begin{array}{l}\text { I prefer that an online shopping mall enables me to order products that are tailor- } \\
\text { made for me. }\end{array}$ \\
\hline & PER3 & I am a unique customer in an online shopping mall. \\
\hline & PER4 & $\begin{array}{l}\text { The advertisements and promotions that an online shopping mall provides are } \\
\text { tailored to my situation. }\end{array}$ \\
\hline & PER5 & $\begin{array}{l}\text { I feel that an online shopping mall will actually deliver the tailor-made services or } \\
\text { products they promise me. }\end{array}$ \\
\hline \multirow[t]{5}{*}{$\begin{array}{l}\text { Responsiveness } \\
\text { (Wolfinbarger \& } \\
\text { Gilly, 2003) }\end{array}$} & RES1 & $\begin{array}{l}\text { When I try to buy something from an online shopping mall, it is important for me } \\
\text { whether the online shopping mall is willing to respond to my inquiries about what } \\
\text { I want to buy. }\end{array}$ \\
\hline & RES2 & $\begin{array}{l}\text { When I have questions about what I want to buy from online shopping mall, it is } \\
\text { important for me that the online shopping mall shows a sincere interest in } \\
\text { answering those questions. }\end{array}$ \\
\hline & RES3 & $\begin{array}{l}\text { When I try to buy something from an online shopping mall, it is important to me } \\
\text { that inquiries are answered promptly. }\end{array}$ \\
\hline & RES4 & $\begin{array}{l}\text { When I try to buy something from an online shopping mall, it is important to me } \\
\text { that the online shopping mall provides information such as FAQs. }\end{array}$ \\
\hline & RES5 & $\begin{array}{l}\text { When I try to buy something from an online shopping mall, it is important for me } \\
\text { that the online shopping mall seems prepared to respond to my inquiry about } \\
\text { what I want to buy. }\end{array}$ \\
\hline
\end{tabular}




\begin{tabular}{|c|c|c|}
\hline \multicolumn{3}{|c|}{ Table 2: continuation } \\
\hline \multirow{4}{*}{$\begin{array}{l}\text { Feedback } \\
\text { (Plamer, 2002; } \\
\text { Torkzadeh \& } \\
\text { Dhillon, 2002) }\end{array}$} & FED1 & $\begin{array}{l}\text { When I try to buy something from an online shopping mall, it is important for me } \\
\text { that the online shopping mall provides mechanisms for feedback. }\end{array}$ \\
\hline & FED2 & $\begin{array}{l}\text { When I try to buy something from an online shopping mall, I like to review } \\
\text { previous feedback before making a purchase. }\end{array}$ \\
\hline & FED3 & I like to provide feedback about what I bought. \\
\hline & FED4 & $\begin{array}{l}\text { When I try to buy something from an online shopping mall, I trust previous } \\
\text { feedback about what I want to buy. }\end{array}$ \\
\hline \multirow{5}{*}{$\begin{array}{l}\text { Product Variety } \\
\text { (Torkzadeh \& } \\
\text { Lhillon, 2002) }\end{array}$} & PRV1 & $\begin{array}{l}\text { It is important to me that an online shopping mall provides a broad choice of } \\
\text { products. }\end{array}$ \\
\hline & PRV2 & $\begin{array}{l}\text { It is important to me that an online shopping mall has greater product selection } \\
\text { than offline shopping mall. }\end{array}$ \\
\hline & PRV3 & $\begin{array}{l}\text { It is important to me to have the maximum product availability when shopping } \\
\text { online. }\end{array}$ \\
\hline & PRV4 & $\begin{array}{l}\text { It is important to me to have the maximum range of product quality options when } \\
\text { shopping online. }\end{array}$ \\
\hline & PRV5 & It is important to me to have the maximum product variety when shopping online. \\
\hline \multirow{5}{*}{$\begin{array}{l}\text { Information } \\
\text { abundance } \\
\text { (Keeney, 1999) }\end{array}$} & INF1 & $\begin{array}{l}\text { It is important to me to have the maximum information available about products } \\
\text { when shopping online. }\end{array}$ \\
\hline & INF2 & $\begin{array}{l}\text { It is important to me to have the maximum available product information } f \text { when } \\
\text { shopping online. }\end{array}$ \\
\hline & INF3 & $\begin{array}{l}\text { It is important to me that an online shopping mall has more product information } \\
\text { than offline shopping mall. }\end{array}$ \\
\hline & INF4 & $\begin{array}{l}\text { It is important to me to have as much information as I can get about products } \\
\text { when shopping online. }\end{array}$ \\
\hline & INF5 & $\begin{array}{l}\text { It is important to me to have the maximum range of product information when } \\
\text { shopping online. }\end{array}$ \\
\hline \multirow{4}{*}{$\begin{array}{l}\text { Ease of Return } \\
\text { and exchange } \\
\text { (Wolfinbarger \& } \\
\text { Gilly, 2003) }\end{array}$} & EAR1 & It is important that I have an easy return policy. \\
\hline & EAR2 & It is important to provide an easy return policy. \\
\hline & EAR3 & Short return and exchange times are important. \\
\hline & EAR4 & It is important to provide reasonable return and exchange policies. \\
\hline \multirow{4}{*}{$\begin{array}{l}\text { Acceptance of } \\
\text { complaints } \\
\text { (Wolfinbarger \& } \\
\text { Gilly, 2003) }\end{array}$} & ACC1 & $\begin{array}{l}\text { It is important that an online shopping mall is willing to respond to my } \\
\text { complaints. }\end{array}$ \\
\hline & ACC2 & $\begin{array}{l}\text { When I have complaints, it is important to me that the online shopping mall } \\
\text { shows a sincere interest in my complaint }\end{array}$ \\
\hline & ACC3 & It is important that complaints are answered promptly \\
\hline & ACC4 & $\begin{array}{l}\text { When I have complaints, it is important to me that customer service personnel } \\
\text { are willing to help me. }\end{array}$ \\
\hline \multirow{4}{*}{$\begin{array}{l}\text { Enjoyment } \\
\text { (Koufaris, 2002) }\end{array}$} & ENJ1 & I found my visit interesting. \\
\hline & ENJ2 & I found my visit enjoyable. \\
\hline & ENJ3 & I found my visit exciting. \\
\hline & ENJ4 & I found my visit fun. \\
\hline \multirow{2}{*}{$\begin{array}{l}\text { Purchase } \\
\text { Involvement } \\
\text { (Pavlou, Liang, } \\
\text { \& Xue, 2007) }\end{array}$} & INV1 & Online shopping is important to me. \\
\hline & INV2 & For me, online shopping does not matter (reverse coded). \\
\hline \multirow{5}{*}{$\begin{array}{l}\text { Intention to } \\
\text { purchase } \\
\text { (Vijayasarathy, } \\
\text { 2003) }\end{array}$} & INT1 & I intend to use an online shopping mall to do my shopping. \\
\hline & INT2 & I intend to use an online shopping mall whenever appropriate to do shopping. \\
\hline & INT3 & I intend to continue to use an online shopping mall in the future. \\
\hline & INT4 & I intend to purchase product from an online shopping mall. \\
\hline & INT5 & I would consider purchasing a product from an online shopping mall. \\
\hline
\end{tabular}

\subsection{Pretest and Scale Refinement}

Two pretests were conducted to check content, flow, scope, and purpose on a group of 12 graduate business students and refine scales by checking reliability on 154 undergraduate business students. For the first pretest, the respondents 
were asked to comment on questions, ambiguities, and redundancy. The questionnaire, which was refined based on feedback, was used for the second pretest. For the second pretest, 154 samples are analyzed to determine the reliability of a measure through Cronbach's alpha. Table 3 provides Cronbach's alpha and descriptive statistics. The results provide the evidence of reliability for most constructs, but feedback and acceptance of complaints have low reliability. To increase reliability, we removed one item each from feedback and acceptance of complaints, respectively.

\subsection{Distinguishing Net-Geners: The Level of Exposure to Technology}

We define Net-geners as the generation born after 1980. Our definition differs from Tapscott's (2008), The Echo Boomers, who were born from 1977 to 1997. Tapscott (2008) includes people who were born from 1977 to 1979 as Net-geners [99]. However, microcomputers, small, low-cost computers that could be owned by individuals and small businesses, became ubiquitous in the 1980s, the first $1 \mathrm{G}$ network and hand-held mobile phones were introduced in 1983 , and the Internet funding of a new U.S. backbone by the National Science Foundation in the 1980s led to worldwide participation and expanded the Internet for popular use in the 1990s.

\subsection{Sampling}

To test the research model, two sets of data were collected via an online survey. All participants are given a chance to win one of five $\$ 100$ cash cards. We surveyed Net-geners and preNet-geners and drew a probability sample of respondents for each type. The Net-geners sample was a set of undergraduates from a cross-section of general business majors. For the preNet-geners sample, data was collected from three pools to increase external validity. For the first set of the preNet-geners data, we employed snowball sampling, asking Net-geners to provide about one adult's information. The second group of respondents was recruited from faculty and staff of private coeducational nonsectarian college-preparatory school. The last participant pool for preNet-geners is parents of the students of the college-preparatory school. Early respondents were those responded within the first two weeks. Each of the two samples were compared based on all the items measured. All t-tests between the means of the early and late respondents showed no significant differences.

Table 3: Descriptive statistics, correlations, and reliabilities for pilot test

\begin{tabular}{|c|c|c|c|c|c|c|c|c|c|c|c|c|}
\hline Variables & Mean & S. D. & 1 & 2 & 3 & 4 & 5 & 6 & 7 & 8 & 9 & 10 \\
\hline Personalization & 3.48 & .50 & .75 & & & & & & & & & \\
\hline Responsiveness & 3.47 & .53 & $.29^{\star \star}$ & .69 & & & & & & & & \\
\hline Feedback & 3.82 & .52 & $.29^{\star \star}$ & $.31^{\star \star}$ & .59 & & & & & & & \\
\hline Product variety & 4.15 & .55 & $.34^{* \star}$ & $.25^{\star *}$ & $.59^{\star \star}$ & .87 & & & & & & \\
\hline $\begin{array}{l}\text { Information } \\
\text { quality }\end{array}$ & 4.42 & .56 & $.22^{\star \star}$ & $.21^{\star \star}$ & $.49^{\star \star}$ & $.65^{\star \star}$ & .90 & & & & & \\
\hline $\begin{array}{l}\text { Information } \\
\text { abundance }\end{array}$ & 4.35 & .62 & $.19^{\star \star}$ & $.15^{*}$ & $.42^{\star \star}$ & $.55^{\star \star}$ & $.76^{\star \star}$ & .89 & & & & \\
\hline $\begin{array}{l}\text { Ease of return } \\
\text { and exchange }\end{array}$ & 4.19 & .55 & .10 & $.17^{\star \star}$ & $.26^{\star \star}$ & $.47^{\star \star}$ & $.57^{* \star}$ & $.47^{* \star}$ & .79 & & & \\
\hline $\begin{array}{l}\text { Acceptance of } \\
\text { complaints }\end{array}$ & 3.88 & .51 & $.29^{\star \star}$ & $.41^{* *}$ & $.40^{\star \star}$ & $.38^{\star \star}$ & $.39^{\star \star}$ & $.43^{\star \star}$ & $37^{\star *}$ & .60 & & \\
\hline Enjoyment & 3.62 & .61 & $.32^{* \star}$ & $.22^{\star \star}$ & $.29^{\star \star}$ & $.36^{\star \star}$ & $20^{\star \star}$ & $.22^{\star \star}$ & $.14^{*}$ & $.35^{\star \star}$ & .87 & \\
\hline $\begin{array}{l}\text { Intention to } \\
\text { purchase }\end{array}$ & 3.88 & .57 & $.23^{\star \star}$ & $.24^{\star \star}$ & $.41^{* \star}$ & $.52^{\star \star}$ & $.34^{* *}$ & $.30^{\star \star}$ & $.27^{* \star}$ & $.34^{* \star}$ & $.47^{* *}$ & .86 \\
\hline
\end{tabular}

Note: Reliabilities (Cronbach's alpha) are reported on the diagonal

${ }^{*}=$ Correlation is significant at the 0.05 level (2-tailed).

** $=$ Correlation is significant at the 0.01 level (2-tailed). 


\section{Data Analysis and Results}

In this section we describe the data analyses we used to test our research model and report the results of our structural equation modeling analyses to compare Net-geners and preNet-geners.

\subsection{Participants}

A total of 539 respondents are summarized in Table 4. The Net-geners sample $(n=293)$ was a set of undergraduates from a cross-section of general business majors. Of the 2140 questionnaires for Net-geners, 350 were returned; 57 of these had to be discarded because of missing or invalid responses (overall response rate for completed valid surveys was 14\%). Of the 1408 questionnaire for preNet-geners, 246 were used for the study (17\%); 22 uncompleted answers were discarded. Nonresponse bias was assessed by verifying that early and late respondents were not significantly different [4].

Table 4: Respondents demographics

\begin{tabular}{|l|l|l|}
\hline Demographics & Net-Geners & PreNet-Geners \\
\hline Gender (percent) & $54 \%^{*}$ & $48 \%$ \\
\hline Male & $59 \%$ & $29 \%$ \\
\hline Female & $41 \%$ & $71 \%$ \\
\hline & & \\
\hline Age & & \\
\hline Under 20 & $5 \%$ & \\
\hline $20-29$ & $49 \%$ & \\
\hline $30-39$ & & $8 \%$ \\
\hline $40-49$ & & $20 \%$ \\
\hline $50-59$ & & $4 \%$ \\
\hline $60-69$ & & $2 \%$ \\
\hline Over 69 & & $1 \%$ \\
\hline Mean age & 24.1 & 48.2 \\
\hline
\end{tabular}

\subsection{Instrument Validity and Reliability}

Convergent validity was assessed by (1) reliability of items, (2) composite reliability of constructs, and (3) average variance extracted (AVE). As shown in Table 5, composite reliability of constructs exceeded the recommended required minimum of 0.80 . Further, AVE, which measures the amount of variance that a construct captures from its indicators relative to the amount due to measurement error, for all constructs exceeded the threshold value of 0.50 . Hence, all three conditions for convergent validity were met. Discriminant validity between constructs was assessed using the relationship between correlations among constructs and the square root of AVEs. As Tables 6 shows, the square root for all the AVEs were greater than the correlations among the constructs, indicating that the discriminant validity criterion was met for all constructs. This pattern supported convergent and discriminant validity.

For reliability, composite reliability and Cronbach's Alpha were assessed (Table 6). For the variables, most of Cronbach's alpha and all composite reliability values were .75 or greater, thus indicating that the measures were reliable. In addition, to assess the correlation of items within each of the measures, a factor analysis verified the number of items underlying each construct. The degree of correlation between the initial raw score and the final factor score is called a factor loading. The factor loadings in all cases except one scale were greater than .65 (Table 7). 
Table 5: Composite reliability and cronbach's alpha

\begin{tabular}{|l|l|l|l|l|}
\hline N=593 & $\begin{array}{l}\text { Number of } \\
\text { items }\end{array}$ & Composite Reliability & Cronbach's Alpha & AVE \\
\hline ACC & 4 & 0.94 & 0.92 & 0.80 \\
\hline EAR & 3 & 0.92 & 0.87 & 0.79 \\
\hline ENJ & 4 & 0.90 & 0.85 & 0.69 \\
\hline FED & 4 & 0.80 & 0.67 & 0.58 \\
\hline INF & 4 & 0.92 & 0.89 & 0.75 \\
\hline INT & 5 & 0.92 & 0.90 & 0.71 \\
\hline INV & 2 & 0.92 & 0.82 & 0.85 \\
\hline PER & 5 & 0.79 & 0.67 & 0.57 \\
\hline PRV & 5 & 0.90 & 0.86 & 0.64 \\
\hline RES & 5 & 0.90 & 0.86 & 0.64 \\
\hline
\end{tabular}

Note: 1. ACC=acceptance of complaints, EAR=ease of return, ENJ=enjoyment, FED=feedback, INF=information abundance, INT=intention to purchase, INV=purchase involvement, PER=personalization, PRV=product variety, RES=responsiveness, $A V E=$ average variance extracted

Table 6: Construct validity tests

\begin{tabular}{|l|r|r|r|r|r|r|r|r|r|r|}
\hline & ACC & EAR & ENJ & FED & INF & INT & INV & PER & PRV & RES \\
\hline ACC & $\mathbf{0 . 9 0}$ & & & & & & & & & \\
\hline EAR & 0.59 & $\mathbf{0 . 8 9}$ & & & & & & & & \\
\hline ENJ & 0.28 & 0.26 & $\mathbf{0 . 8 3}$ & & & & & & & \\
\hline FED & 0.45 & 0.29 & 0.32 & $\mathbf{0 . 7 1}$ & & & & & & \\
\hline INF & 0.64 & 0.52 & 0.27 & 0.47 & $\mathbf{0 . 8 7}$ & & & & & \\
\hline INT & 0.59 & 0.45 & 0.37 & 0.48 & 0.49 & $\mathbf{0 . 8 4}$ & & & & \\
\hline INV & 0.44 & 0.29 & 0.31 & 0.39 & 0.35 & 0.66 & $\mathbf{0 . 9 2}$ & & & \\
\hline PER & 0.22 & 0.17 & 0.43 & 0.38 & 0.24 & 0.43 & 0.28 & $\mathbf{0 . 6 6}$ & & \\
\hline PRV & 0.41 & 0.39 & 0.36 & 0.36 & 0.46 & 0.47 & 0.28 & 0.34 & $\mathbf{0 . 8 0}$ & \\
\hline RES & 0.69 & 0.56 & 0.29 & 0.48 & 0.64 & 0.58 & 0.43 & 0.27 & 0.48 & $\mathbf{0 . 8 0}$ \\
\hline
\end{tabular}

Note: $1 . A C C=a c c e p t a n c e$ of complaints, EAR=ease of return, ENJ=enjoyment, FED=feedback, INF=information abundance, INT =intention to purchase, INV=purchase involvement, PER=personalization, PRV=product variety, RES=responsiveness.

2. The diagonal (in bold) represents the square roots of AVE.

\subsection{Results}

A structural equation modeling (SEM) approach was used to measure relationships from shopping factors to intention to purchase. This method was applied because it tests structural and measurement models and provides a complete analysis for interrelationships in a model. A variance-based partial least squares (PLS-SEM) method, a nonparametric statistical method, was chosen over covariance-based SEM as it supports both exploratory and confirmatory research [33], [90] and does not require the data to be normally distributed [36]. In addition, this approach to SEM has advantages when the model in questions is used for predictive purpose instead of theory testing [47], [90]. PLS-SEM does not generate an overall goodness-of-fit index (as with linear structural relations models, or LISREL), so model validity is assessed by examining structural paths and $R 2$ values.

Given the non-probabilistic nature of the samples, PLS-SEM Bootstrapping was performed to test statistical significance of each path coefficient (Table 8). PLS-SEM relies on a nonparametric bootstrap procedure which creates subsamples with randomly drawn observations from the original set of data with replacement. Then, the subsample is used to estimate our PLS path model. This process is repeated until a large number of random subsamples has been created. As recommended [36], 5,000 subsamples have randomly drawn from the original data set to test the current PLS path model. 
Table 7: Cross loading

\begin{tabular}{|c|c|c|c|c|c|c|c|c|c|c|}
\hline & INV & INT & PER & RES & FED & PRV & INF & EAR & ACC & ENJ \\
\hline INV1 & 0.94 & 0.67 & 0.31 & 0.46 & 0.43 & 0.33 & 0.40 & 0.33 & 0.47 & 0.37 \\
\hline INV2 & 0.90 & 0.54 & 0.20 & 0.32 & 0.28 & 0.17 & 0.24 & 0.19 & 0.33 & 0.18 \\
\hline INT1 & 0.61 & 0.79 & 0.33 & 0.40 & 0.32 & 0.29 & 0.30 & 0.31 & 0.47 & 0.30 \\
\hline INT2 & 0.51 & 0.78 & 0.37 & 0.53 & 0.40 & 0.39 & 0.44 & 0.31 & 0.46 & 0.32 \\
\hline INT3 & 0.61 & 0.92 & 0.39 & 0.54 & 0.47 & 0.48 & 0.47 & 0.42 & 0.55 & 0.36 \\
\hline INT4 & 0.57 & 0.90 & 0.37 & 0.44 & 0.39 & 0.40 & 0.42 & 0.40 & 0.48 & 0.33 \\
\hline INT5 & 0.49 & 0.81 & 0.34 & 0.53 & 0.43 & 0.42 & 0.41 & 0.44 & 0.52 & 0.26 \\
\hline PER1 & 0.17 & 0.26 & 0.66 & 0.21 & 0.29 & 0.22 & 0.10 & 0.10 & 0.16 & 0.26 \\
\hline PER2 & 0.13 & 0.24 & 0.65 & 0.19 & 0.24 & 0.26 & 0.19 & 0.09 & 0.12 & 0.27 \\
\hline PER3 & 0.12 & 0.26 & 0.62 & 0.13 & 0.18 & 0.16 & 0.17 & 0.10 & 0.10 & 0.24 \\
\hline PER4 & 0.22 & 0.24 & 0.63 & 0.19 & 0.28 & 0.22 & 0.16 & 0.13 & 0.17 & 0.31 \\
\hline PER5 & 0.26 & 0.36 & 0.72 & 0.18 & 0.26 & 0.25 & 0.16 & 0.14 & 0.15 & 0.32 \\
\hline RES1 & 0.35 & 0.50 & 0.23 & 0.79 & 0.36 & 0.41 & 0.50 & 0.41 & 0.56 & 0.21 \\
\hline RES2 & 0.35 & 0.46 & 0.24 & 0.84 & 0.37 & 0.37 & 0.49 & 0.46 & 0.56 & 0.22 \\
\hline RES3 & 0.35 & 0.51 & 0.21 & 0.85 & 0.37 & 0.43 & 0.52 & 0.51 & 0.64 & 0.17 \\
\hline RES4 & 0.32 & 0.38 & 0.27 & 0.69 & 0.44 & 0.32 & 0.48 & 0.36 & 0.40 & 0.29 \\
\hline RES5 & 0.34 & 0.44 & 0.16 & 0.82 & 0.42 & 0.39 & 0.57 & 0.48 & 0.58 & 0.28 \\
\hline FED1 & 0.24 & 0.29 & 0.13 & 0.46 & 0.68 & 0.23 & 0.40 & 0.24 & 0.43 & 0.24 \\
\hline FED2 & 0.36 & 0.40 & 0.27 & 0.42 & 0.77 & 0.30 & 0.42 & 0.27 & 0.41 & 0.19 \\
\hline FED3 & 0.18 & 0.27 & 0.22 & 0.19 & 0.64 & 0.16 & 0.20 & 0.09 & 0.15 & 0.23 \\
\hline FED4 & 0.30 & 0.37 & 0.42 & 0.30 & 0.75 & 0.30 & 0.28 & 0.20 & 0.26 & 0.27 \\
\hline PRV1 & 0.23 & 0.36 & 0.25 & 0.39 & 0.34 & 0.75 & 0.36 & 0.28 & 0.33 & 0.25 \\
\hline PRV2 & 0.19 & 0.31 & 0.22 & 0.30 & 0.27 & 0.71 & 0.32 & 0.22 & 0.26 & 0.25 \\
\hline PRV3 & 0.20 & 0.37 & 0.28 & 0.39 & 0.25 & 0.85 & 0.40 & 0.32 & 0.31 & 0.29 \\
\hline PRV4 & 0.25 & 0.44 & 0.27 & 0.43 & 0.29 & 0.82 & 0.41 & 0.42 & 0.36 & 0.29 \\
\hline PRV5 & 0.24 & 0.38 & 0.34 & 0.38 & 0.28 & 0.85 & 0.34 & 0.29 & 0.34 & 0.34 \\
\hline INF1 & 0.33 & 0.43 & 0.21 & 0.58 & 0.42 & 0.42 & 0.88 & 0.46 & 0.55 & 0.23 \\
\hline INF2 & 0.29 & 0.39 & 0.15 & 0.55 & 0.38 & 0.39 & 0.85 & 0.46 & 0.56 & 0.21 \\
\hline INF3 & 0.33 & 0.45 & 0.24 & 0.57 & 0.41 & 0.37 & 0.87 & 0.43 & 0.58 & 0.21 \\
\hline INF4 & 0.28 & 0.42 & 0.23 & 0.52 & 0.41 & 0.42 & 0.86 & 0.46 & 0.52 & 0.28 \\
\hline EAR1 & 0.23 & 0.40 & 0.15 & 0.50 & 0.25 & 0.37 & 0.47 & 0.93 & 0.54 & 0.25 \\
\hline EAR2 & 0.30 & 0.44 & 0.18 & 0.56 & 0.30 & 0.42 & 0.50 & 0.93 & 0.56 & 0.22 \\
\hline EAR3 & 0.23 & 0.34 & 0.12 & 0.41 & 0.22 & 0.25 & 0.42 & 0.81 & 0.47 & 0.21 \\
\hline $\mathrm{ACC} 1$ & 0.41 & 0.55 & 0.17 & 0.59 & 0.40 & 0.33 & 0.55 & 0.50 & 0.89 & 0.26 \\
\hline ACC2 & 0.42 & 0.53 & 0.21 & 0.64 & 0.46 & 0.39 & 0.57 & 0.50 & 0.91 & 0.26 \\
\hline ACC3 & 0.37 & 0.52 & 0.18 & 0.61 & 0.37 & 0.34 & 0.62 & 0.54 & 0.89 & 0.22 \\
\hline ACC4 & 0.39 & 0.53 & 0.22 & 0.64 & 0.39 & 0.39 & 0.56 & 0.58 & 0.90 & 0.27 \\
\hline ENJ1 & 0.29 & 0.34 & 0.31 & 0.34 & 0.29 & 0.31 & 0.34 & 0.27 & 0.33 & 0.80 \\
\hline ENJ2 & 0.19 & 0.23 & 0.33 & 0.20 & 0.21 & 0.26 & 0.16 & 0.22 & 0.22 & 0.80 \\
\hline ENJ3 & 0.27 & 0.32 & 0.39 & 0.19 & 0.30 & 0.29 & 0.17 & 0.17 & 0.16 & 0.85 \\
\hline ENJ4 & 0.26 & 0.33 & 0.39 & 0.21 & 0.26 & 0.33 & 0.20 & 0.21 & 0.21 & 0.87 \\
\hline
\end{tabular}

Note: 1 . ACC=acceptance of complaints, EAR=ease of return, ENJ=enjoyment, FED=feedback, INF=information abundance, INT =intention to purchase, INV=purchase involvement, PER=personalization, PRV=product variety, RES=responsiveness. 
Table 8: PLS-SEM bootstrapping

\begin{tabular}{|l|l|l|l|}
\hline N=593 & $\begin{array}{l}\text { Number of } \\
\text { items }\end{array}$ & Composite Reliability & Cronbach's Alpha \\
\hline ACC & 4 & 0.94 & 0.92 \\
\hline EAR & 3 & 0.92 & 0.87 \\
\hline ENJ & 4 & 0.90 & 0.85 \\
\hline FED & 4 & 0.80 & 0.67 \\
\hline INF & 4 & 0.92 & 0.89 \\
\hline INT & 5 & 0.92 & 0.90 \\
\hline INV & 2 & 0.92 & 0.82 \\
\hline PER & 5 & 0.79 & 0.67 \\
\hline PRV & 5 & 0.90 & 0.86 \\
\hline RES & 5 & 0.90 & 0.86 \\
\hline
\end{tabular}

Note: 1 . ACC=acceptance of complaints, EAR=ease of return, ENJ=enjoyment, FED=feedback, $\mathrm{INF}=$ information abundance, INT =intention to purchase, INV=purchase involvement, $\mathrm{PER}=$ personalization, $\mathrm{PRV}=$ product variety, $\mathrm{RES}=$ responsiveness.

In addition, PLS- SEM has been widely applied to estimate structural equation models for small samples where the variables do not follow a multivariate-normal distribution [34], [116]. The heuristic is that the sample size should at least 10 times the number of incoming paths to the construct with the most incoming paths [34], [35], which is nine. In addition to the 10 times rule, sample size was computed based on the number of observed and latent variables, the anticipated effect size, and the desired probability and statistical power levels. Note that Daniel Soper's statistics calculator used with the following parameters: the number of observed variables (41), the number of latent variables (10), the anticipated effect size (0.2), and the desired probability level (0.05), and statistical power level (0.9).. Accordingly,the recommended minimum sample size is 111 for each model. Therefore, the minimum sample size to run our model using PLS is 111, and a sample size of 293 for Net-geners' model and 246 for preNet-geners' model should be sufficient.

\subsection{Net-Geners}

Figure 2 shows the results of the PLS analysis for Net-geners. All paths from the shopping factors but two paths are statistically significant with the intention to purchase with the exception of information abundance and ease of return to the intention to purchase, which is not significant. Variance captured by the shopping factors in this model is high $(\mathrm{R} 2=0.8)$. The results support all hypotheses but $\mathrm{H} 2$ and $\mathrm{H} 7$ (Table 9). Of two constructs in the information phase, product variety $(\beta=0.168, p<0.01)$ has a positive and significant causal relationship with intention to purchase. Three constructs (feedback, $\beta=0.148, p<0.01$; responsiveness, $\beta=0.163, p<0.05$; personalization, $\beta=0.263, p<0.001$ ) of agreement phase are related to intention to purchase. One settlement phase variable, acceptance of complaints $(\beta=$ $0.173, p<0.01$ ), significantly affects intention to purchase. All constructs of the environment phase (enjoyment, $\beta=$ $0.116, p<0.05$; purchase involvement, $\beta=0.231, p<0.001$ ) are related to our dependent variable. 


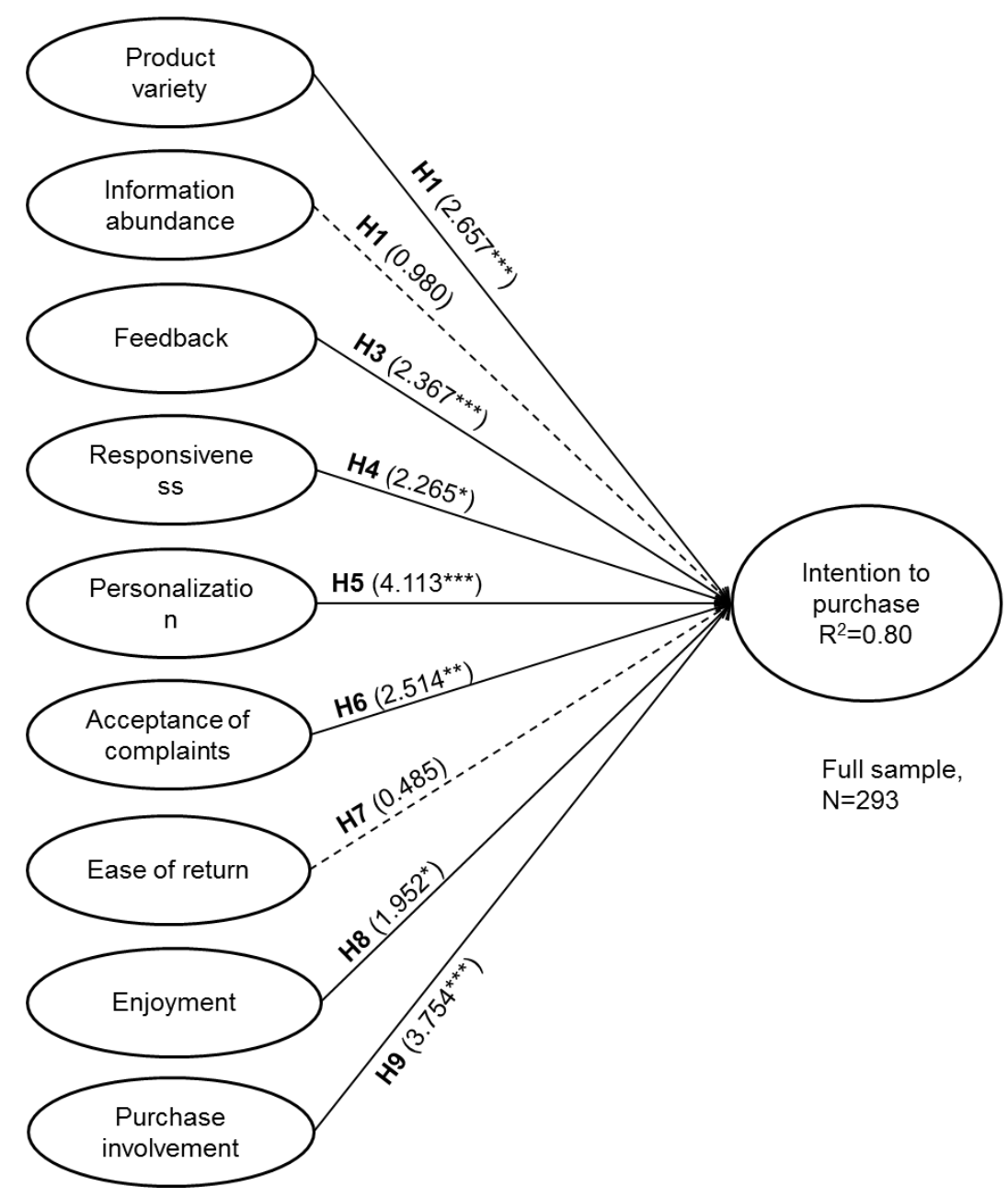

${ }^{*} p<0.05,{ }^{* *} p<0.01,{ }^{* * *} p<0.001$. T-value for full sample results are listed in parentheses. The dotted lines are not a significant relation.

Figure 2: PLS results of net-geners

Table 9: Results of hypothesis testing (net-geners)

\begin{tabular}{|c|c|c|c|c|c|}
\hline Hypothesis & Causal path & $\begin{array}{l}\text { Path } \\
\text { coefficient }\end{array}$ & t-value & Significance & Supported \\
\hline $\mathrm{H} 1$ & $\begin{array}{l}\text { Product variety } \rightarrow \text { Intention to } \\
\text { purchase }\end{array}$ & 0.168 & 2.567 & Significance $^{* *}$ & Yes \\
\hline $\mathrm{H} 2$ & $\begin{array}{l}\text { Information abundance } \rightarrow \text { Intention } \\
\text { to purchase }\end{array}$ & 0.062 & 0.980 & NS & No \\
\hline $\mathrm{H} 3$ & Feedback $\rightarrow$ Intention to purchase & 0.148 & 2.367 & Significance ${ }^{\star \star}$ & Yes \\
\hline $\mathrm{H} 4$ & $\begin{array}{l}\text { Responsiveness } \rightarrow \text { Intention to } \\
\text { purchase }\end{array}$ & 0.163 & 2.265 & Significance* & Yes \\
\hline H5 & $\begin{array}{l}\text { Personalization } \rightarrow \text { Intention to } \\
\text { purchase }\end{array}$ & 0.261 & 4.113 & Significance ${ }^{\star * \star}$ & Yes \\
\hline $\mathrm{H} 6$ & $\begin{array}{l}\text { Acceptance of complaints } \rightarrow \\
\text { Intention to purchase }\end{array}$ & 0.173 & 2.514 & Significance** & Yes \\
\hline $\mathrm{H} 7$ & $\begin{array}{l}\text { Ease of return } \rightarrow \text { Intention to } \\
\text { purchase }\end{array}$ & 0.022 & 0.485 & NS & No \\
\hline H8 & Enjoyment $\rightarrow$ Intention to purchase & 0.115 & 1.952 & Significance* $^{*}$ & Yes \\
\hline H9 & $\begin{array}{l}\text { Purchase involvement } \rightarrow \text { Intention } \\
\text { to purchase }\end{array}$ & 0.231 & 3.754 & Significance ${ }^{\star \star \star}$ & Yes \\
\hline
\end{tabular}

Note: ${ }^{*} p<0.05,{ }^{* *} p<0.01,{ }^{* *} p<0.001$. NS $=$ Not significance 
Table 10: Results of the PLS (prenet-geners)

\begin{tabular}{|l|l|l|l|}
\hline Causal path & $\begin{array}{l}\text { Path } \\
\text { coefficient }\end{array}$ & t-value & Significance \\
\hline Product variety $\rightarrow$ Intention to purchase & 0.082 & 1.004 & $\mathrm{NS}$ \\
\hline Information abundance $\rightarrow$ Intention to purchase & 0.035 & 0.352 & $\mathrm{NS}$ \\
\hline Feedback $\rightarrow$ Intention to purchase & -0.020 & 0.336 & $\mathrm{NS}$ \\
\hline Responsiveness $\rightarrow$ Intention to purchase & 0.060 & 0.357 & $\mathrm{NS}$ \\
\hline Personalization $\rightarrow$ Intention to purchase & 0.140 & 1.981 & Significance \\
\hline Acceptance of complaints $\rightarrow$ Intention to purchase & 0.089 & 0.590 & NS \\
\hline Ease of return $\rightarrow$ Intention to purchase & 0.076 & 1.012 & NS \\
\hline Enjoyment $\rightarrow$ Intention to purchase & -0.035 & 0.769 & NS \\
\hline Purchase involvement $\rightarrow$ Intention to purchase & 0.556 & 6.154 & Significance ${ }^{* * *}$ \\
\hline Note ${ }^{*}$ p $<0.05,{ }^{* *}$ p $<0.01,{ }^{* * *}$ p $<0.001$ NS $=$ Not significance & & \\
\hline
\end{tabular}

Note: ${ }^{*} p<0.05,{ }^{* *} p<0.01,{ }^{* * *} p<0.001$. NS $=$ Not significance

\subsection{Comparison of Net-Geners with PreNet-Geners}

To test Hypotheses from $\mathrm{H} 1-1$ to $\mathrm{H} 9-1$, the comparison of the path significances of two PLS results and a correlation coefficients comparing method were conducted: Net-geners vs. preNet-geners. The first phase is to analyze preNetgeners' data with SmartPLS (Table 10 and Figure 3). As a results, only two causal paths are verified (personalization, $\beta=0.147, p<0.05$; purchase involvement, $\beta=0.558, p<0.001$ ). In the last phase, the correlation coefficients between the shopping variables and intention of purchase for two groups were compared through z-score difference test [3] $p$. 268. Since Pearson's $r$ is not normally distributed, we have chosen the $z$-score difference test, which can adjust $r$ so that its sampling distribution is normal [3]. The format of this test is $Z_{\text {Difference }}=(z r 1-z r 2) / s q r t(1 /(N 1-3)+1 /(N 2-3))$, where $\mathrm{zr} 1=\mathrm{Z}$ score of correlation coefficient of data 1 (Net-geners), zr2 = Z score of correlation coefficient of data 2 (preNetgeners), $\mathrm{N} 1$ = sample size of data 1 , and $\mathrm{N} 2$ = sample size of data 2 . This test ensures whether the correlations between the shopping factors and intention to purchase are significantly different in Net-geners and preNet-geners. For example, for Net-geners and preNet-geners, the correlation coefficient between the "feedback" variable is 0.673 and 0.3442 , respectively and, according to the formula, $Z_{\text {Difference }}$ is 3.95 , which is significant. Table 11 presents the results of the z-score difference test.

The results of the tests support all hypotheses with the exception of $\mathrm{H} 2-1, \mathrm{H} 7-1$, and $\mathrm{H} 9-1$. Table 12 represents the results of hypothesis testing. While product variety $(\mathrm{H} 1-1)$, feedback $(\mathrm{H} 3-1)$, responsiveness $(\mathrm{H} 4-1)$, acceptance of complaints (H6-1), and enjoyment (H8-1) are significantly and positively associated with Net-geners' intention to purchase, these are not significant for preNet-geners. In addition, the correlation coefficients were significantly different (product variety, $Z_{\text {Difference }}=4.8, p<0.000$; feedback, $Z_{\text {Difference }}=5.26, p<0.000$; responsiveness, $Z_{\text {Difference }}=3.43, p<$ 0.0001 ; acceptance of complaints, $Z_{\text {Difference }}=3.95, p<0.0001$; enjoyment, $Z_{\text {Difference }}=4.97, p<0.000$ ). Personalization $(\mathrm{H} 5-1)$ is supported because even though personalization is significantly and positively related to intention to purchase for both groups, the significance level of personalization for Net-geners $(p<0.001)$ is higher than that of preNet-geners $(p<0.05)$, and the correlation coefficients were significantly different $\left(Z_{\text {Difference }}=6.63, p<0.000\right)$. Information abundance $(\mathrm{H} 2-1)$ and purchase involvement $(\mathrm{H} 7-1)$ were not supported since both Net-geners and preNet-geners don't have significant relationships with intention to purchase, and the correlation coefficients were not different from each other. Purchase involvement (H9-1) is also not supported because not only are the significant causal relationships with intention to purchase revealed for both groups, but also the correlation coefficients are not significantly different. 


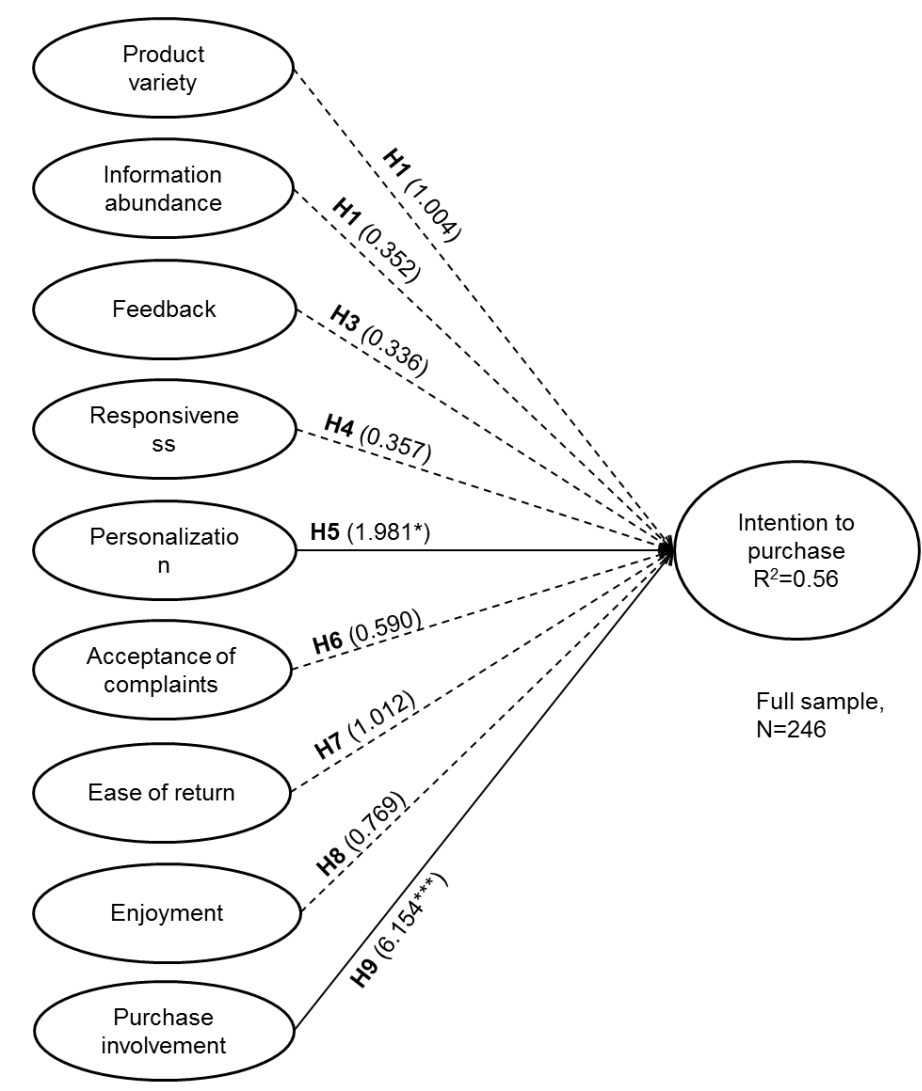

${ }^{*} p<0.05,{ }^{* *} p<0.01,{ }^{* * *} p<0.001$. T-value for full sample results are listed in parentheses. The dotted lines are not a significant relation.

Figure 3: PLS results of preNet-geners

Table 11: Results of correlation coefficient comparing

\begin{tabular}{|c|c|c|c|c|c|c|}
\hline Variables & $\begin{array}{l}\text { Correlation } \\
\text { coefficient } \\
\text { Net-geners }\end{array}$ & $\begin{array}{l}\text { Correlation } \\
\text { coefficient } \\
\text { preNet- } \\
\text { geners }\end{array}$ & $\begin{array}{l}\text { Z score } \\
\text { Net- } \\
\text { geners }\end{array}$ & $\begin{array}{l}\text { Z score } \\
\text { preNet- } \\
\text { geners }\end{array}$ & ZDifference & Significance \\
\hline Product variety & 0.650 & 0.342 & 0.774 & 0.357 & 4.804 & Significance ${ }^{* \star *}$ \\
\hline $\begin{array}{l}\text { Information } \\
\text { abundance }\end{array}$ & 0.528 & 0.459 & 0.587 & 0.496 & 1.042 & NS \\
\hline Feedback & 0.673 & 0.344 & 0.816 & 0.359 & 5.260 & Significance ${ }^{\star \star *}$ \\
\hline Responsiveness & 0.687 & 0.495 & 0.842 & 0.543 & 3.436 & Significance $e^{* * *}$ \\
\hline Personalization & 0.719 & 0.317 & 0.905 & 0.328 & 6.630 & Significance ${ }^{* * *}$ \\
\hline $\begin{array}{l}\text { Acceptance of } \\
\text { complaints }\end{array}$ & 0.717 & 0.507 & 0.902 & 0.558 & 3.950 & Significance ${ }^{\star \star *}$ \\
\hline Ease of return & 0.451 & 0.459 & 0.486 & 0.496 & 0.115 & NS \\
\hline Enjoyment & 0.575 & 0.219 & 0.655 & 0.223 & 4.977 & Significance ${ }^{* * *}$ \\
\hline $\begin{array}{l}\text { Purchase } \\
\text { involvement }\end{array}$ & 0.636 & 0.695 & 0.752 & 0.858 & 1.227 & NS \\
\hline
\end{tabular}

Note: Correlation with intention to purchase. $Z$ score $=(1 / 2) \operatorname{loge}((1+r) /(1-r))$, where $r=$ correlation coefficient. ${ }^{*} p<0.05,{ }^{* *} p<0.01$, ${ }^{* * *} p<0.001$. NS $=$ Not significance

\section{Discussion}

The premise of the paper was that Net generation (Net-geners) may use different features of the online shopping malls for some phase of the online purchase process. This research focused on generation differences in the theoretically grounded determinants of online purchase intention. We understood online purchase behaviors of Net-geners during the online shopping and hypothesized that the unique characteristics of Net-geners would result in different priority of factors that affect online purchase behavior. 
Our findings consistently show that Net-geners consider a wide variety of product selection in information phase of online shopping. In agreement phase, high feedback quality and the quick and sincere responses from vendors are critical factors to fulfill the basic and inherent desire. In settlement phase, easy return policy and genuine willingness of complaint acceptance are important to Net-geners for final purchase decision in the online shopping environment. Last, enjoyment and purchase involvement are revealed as the vital antecedents of online purchase decision in environment phase.

Table 12: Results of Hypothesis Testing (Comparison of Net-geners with PreNet-geners)

\begin{tabular}{|c|c|c|c|c|c|}
\hline Hypothesis & Causal path & $\begin{array}{l}\text { Net-geners } \\
\text { path } \\
\text { Significance }\end{array}$ & $\begin{array}{l}\text { PreNet-geners } \\
\text { path } \\
\text { Significance } \\
\end{array}$ & $\begin{array}{l}\text { Correlation } \\
\text { coefficient } \\
\text { difference test }\end{array}$ & $\begin{array}{l}\text { Hypothesis } \\
\text { supported }\end{array}$ \\
\hline $\mathrm{H} 1-1$ & $\begin{array}{l}\text { Product variety } \rightarrow \\
\text { Intention to purchase }\end{array}$ & Significance ${ }^{\star \star}$ & NS & Significance ${ }^{\star \star \star}$ & Yes \\
\hline $\mathrm{H} 2-1$ & $\begin{array}{l}\text { Information abundance } \rightarrow \\
\text { Intention to purchase }\end{array}$ & NS & NS & NS & No \\
\hline H3-1 & $\begin{array}{l}\text { Feedback } \rightarrow \text { Intention to } \\
\text { purchase }\end{array}$ & Significance ${ }^{\star *}$ & NS & Significance ${ }^{\star \star *}$ & Yes \\
\hline $\mathrm{H} 4-1$ & $\begin{array}{l}\text { Responsiveness } \rightarrow \\
\text { Intention to purchase }\end{array}$ & Significance* & NS & Significance ${ }^{* * *}$ & Yes \\
\hline H5-1 & $\begin{array}{l}\text { Personalization } \rightarrow \\
\text { Intention to purchase }\end{array}$ & Significance ${ }^{\star \star \star}$ & Significance* & Significance ${ }^{\star \star \star}$ & Yes \\
\hline H6-1 & $\begin{array}{l}\text { Acceptance of } \\
\text { complaints } \rightarrow \text { Intention to } \\
\text { purchase }\end{array}$ & Significance ${ }^{\star *}$ & NS & Significance ${ }^{* * *}$ & Yes \\
\hline $\mathrm{H} 7-1$ & $\begin{array}{l}\text { Ease of return } \rightarrow \text { Intention } \\
\text { to purchase }\end{array}$ & NS & NS & NS & No \\
\hline $\mathrm{H} 8-1$ & $\begin{array}{l}\text { Enjoyment } \rightarrow \text { Intention to } \\
\text { purchase }\end{array}$ & Significance* & NS & Significance ${ }^{\star \star \star}$ & Yes \\
\hline H9-1 & $\begin{array}{l}\text { Purchase involvement } \rightarrow \\
\text { Intention to purchase }\end{array}$ & Significance ${ }^{\star \star \star}$ & Significance ${ }^{\star \star \star}$ & NS & No \\
\hline
\end{tabular}

Note: ${ }^{*} p<0.05,{ }^{* *} p<0.01,{ }^{* * *} p<0.001$. NS $=$ Not significance

The second key finding is that interestingly most of the online purchase determinant factors between two generations are significantly different; a variety of product selection in online shopping is more important to Net-geners' online purchase decision than preNet-geners. This result corresponds with prior ethnographic studies that have shown that Net-geners have the sophisticated and inherent comparing ability and online shopping expertise, while preNet-geners are unaccustomed to surfing for tremendous choices, hindering their primary purpose of a utilitarian for using online shopping [68], [99]. In agreement phase, to establish a contract Net-geners are more willing to communicate with sellers than preNet-geners by reading and writing feedbacks, accepting customized recommendations from sellers, and asking more inquires to sellers. In addition, to settle down a transaction, Net-geners have been shown to disapprove of unexpected results such as mismatching and products not meeting expectations, whereas preNetgeners, on the other hand, are more likely to admit their complaints instead of expressing them to sellers. Accordingly, for Net-geners, expressing complaints can be interpreted as of a way of pursuing their rights. Hence, Net-geners' valuing of acceptance of their complaints about transaction aligns with their affinity for pursuing their right, while preNetgeners' discounting of acceptance of their complaints aligns with their dislike of making a problem and spending extra time for online shopping. This study also showed that the effect of enjoyment on intention to purchase was stronger for Net-geners than for preNet-geners. Net-geners, as hedonic users, consider the online shopping a tool of play such as window shopping, which is corresponded with prior literature that illustrates that the level of intrinsic enjoyment of the shopping experiences is positively associated with hedonic users' online purchase behavior [80], whereas utilitarian focused on minimizing search cost [66], [68].

One of the interesting findings is the relationships between purchase involvement and intention to purchase. According to previous researches, purchase involvement influence purchase decision making, risk perception, product attitude, and purchase intention [23]. While customers are more likely to involve purchases related to expensive, relevant, and durable goods such as a car, they are less likely to involve purchases associated with low price, non-durable, and low relevant products such as books. For high involvement purchases, a consumer are more likely to evaluate risk and uncertainty associated a product, which requires more information search and spent time and effort in order to reduce the probabilities of losses occurring from product purchase. Therefore, high involvement purchase is negatively related to purchase intention due to high perceived risk and uncertainty in online shopping due to the spatial and temporal separation nature of online environment [81].

However, this study showed different results which are that purchase involvement is positively related to intention to purchase. The different results from previous studies are attributed to the different sources of involvement. Even though most studies including Pavlou et al. (2007)'s study explicitly didn't reveal the source of involvement, the source is a product or product category [82]. On the other hand, the current study investigated the relationships between involvements in online shopping rather than a specific product and intention to purchase. Drawing on Laurent and 
Kapferer (1985)'s involvement profiling study, it can be called as "the perceived importance of the online shopping" [60]. We feel there is an opportunity to investigate perceived importance in future research.

\section{Conclusion}

The fundamental purpose of the current study is to reveal the difference in the online purchase behavior of Net-geners from the preNet generation. Based on the understanding the characteristics of Net-geners, we developed and empirically tested hypotheses. The results complement prior work by (1) providing an analysis of a newly-emerging powerful and populous buying group, (2) studying the difference of online purchase behavior between Net-geners and preNet-geners, and (3) going beyond prior research in how social change reflects on online shopping research. Taken as a whole, the results will support an interesting theoretical picture of the effects of factors on online shopping success. Even though the basic premises put forth in the paper will be supported, the results also serve to highlight many avenues for future research to expend our understanding of online purchase behavior of the Net generation.

\subsection{Implications for Research}

From a theoretical perspective, combining the generational behavior related to information technology, this study identifies two generational groups: the Net generation (Net-geners) and the pre Net generation (preNet-geners). Drawing from online purchase behaviors and generation literature, the current research develops a model to test the difference in online purchase behavior of the two groups. To the best of our knowledge, this is the first crossgenerational comparison study of online purchase behavior determinants. This study empirically tests the model using cross-generational data collected from two generations typically representing Net-geners and preNet-geners. The results of the study support the theoretical argument that online purchase determinant factors differently work in the two groups. These results contribute to online shopping mall success in a variety of ways. The results demonstrate that Net-geners are active to online shopping. They want to select, interact, control, and enjoy shopping. Thus, the study improves our understanding of not only the unique online purchase behavior of Net-geners but also shows the factors that are important to making purchase decision.

Furthermore, this study demonstrates the value of using the Selz and Schubert (1997)'s transaction process framework to understand the online purchase behavior of Net-geners [92]. As correctly stated by previous research [53], traditional views of web assessment have not provided a useful structure for understanding complex online purchase behavior. The current research suggests an alternative framework to study e-commerce and is found to be of value. One direction for future research would be to extend the proposed framework to a specific e-commerce domain and to replicate this study across a broader range of cultures. Even though this study utilized framework to investigate the general online purchase behavior, we may correctly understand how differently the framework works for distinct products in online environment if following studies examine a focal product domain by the framework. In addition, given the global nature of e-commerce, we should comprehend how differently the framework works in several cultures.

\subsection{Implications for Practice}

The results of this study have several important implications for practice. They can be used to inform the development of guidelines for the online shopping mall by practitioners. The proposed model describes a concrete set of factor that helps practitioners set up strategies varying among generations. First, variety of product presentations may enhance web site content and provide opportunities for Net-geners to customize their experiences. Second, an online shopping mall that deals with Net-geners-oriented products can place more of its sources on providing a sense of social presence by offering the interactivity. That is, web sites should also offer mechanisms for feedback and answering user questions. As Internet technologies and social media diffuse, these interactive online experience strategies, including social networking, become even more critical. Third, interestingly, this study suggests the importance of after-sales services such as a straightforward and fast return policy. This result argues that web sites should offer not only customer service in agreement phase but also settlement phase to make long-term relationships with customers and maintain good reputations. Finally, the results of this study inform practitioners that Net-geners are looking for an attractive online shopping mall, which does not necessarily mean that they expect an easy and effective web site; rather, they seem to be looking for online shopping malls that offer fun.

\subsection{Limitation and Future Studies}

This study has a number of limitations that create some interesting opportunities for future research. Perhaps the most significant limitation of the current study is that we will be not able to measure virtual online purchase behavior. We tested the model with the perceived data which includes the possible presence of social desirability bias when selfreporting E-commerce Intention to use. Even though the intention of system usage or information technology usage construct has played a central role in information systems research since 1970s, the intention construct over time has been operationalized by a diverse set of unsystematized measures [12]. A systematic approach for reconceptualizing the IT artifact usage construct to overcome the lack of theory and lack of validation in prior usage construct studies would be helpful in the future. For example, the self-reported survey method to measure usage construct in the current study may have systematic errors. Even though it is difficult to get actual usage data, this problem would be reduced 
(or eliminated) by using actual usage data. An experimental study could understand online customer purchase behavior rigorously. There are two recommended experimental research studies. One possible study is based on an experimental site that is developed by researcher for study only. From this experiment, the researcher could observe the effect of treatment, for example, the existence of personalization offering. The second method captures more reality with more difficulty. Based on data from existing online shopping malls, the hypothesis would be empirically verified. Another important limitation of the current study stems from the process to distinguish Net-geners. To determine Netgeners is not just an age phenomenon, but perhaps exposure to technology could be more involved [74]. But, for some multi-characteristics subjects, it is difficult to measure the level of exposure to technology. Rigorous criteria are required for further study to understand the Net-geners. Finally, the use of student subjects may limit the generalizability of our findings. Undergraduate student are not completely representative of the entire population of Net-geners whose online purchase behavior we would like to model. However, we expect this problem to be minimal since results reported in prior IT usage studies that employed student subjects do not appear to be systematically different from those employing general users. In addition, the undergraduate subjects in our study may be representative of the younger collegeeducated segment of end users.

\section{References}

[1] J. Alba and W. Hutchinson, Dimensions of consumer expertise, Journal of Consumer Research, vol. 13, no. 24, pp. 411-454, 1987.

[2] N. Amblee and T. Bui, Harnessing the influence of social proof in online shopping: the effect of electronic word of mouth on sales of digital microproducts, International Journal of Electronic Commerce, vol. 16, no. 2, pp. 91$113,2011-2012$.

[3] F. Andy, Discovering Statistics Using IBM SPSS Statistics IBM book. Thousand Oaks, CA: SAGE Publications, 2013.

[4] J. B. Armstrong and T. S. Overton, Estimating nonresponse bias in mail surveys, Journal of Marketing Research, vol. 14, no. 3, pp. 396-402, 1977.

[5] K.Bagchi, P.Kirs and F. Lopez, The impact of price decreases on telephone and cell phone diffusion, Information \& Management, vol. 45, no. 3, pp. 183-193, 2008.

[6] I. Benbasat and H. Barki, Quo vadis TAM?, Journal of the Association for Information Systems, vol. 8, no. 4, pp. 219-222, 2007.

[7] A. Benlian, R. Titah and T. Hess, Differential effects of provider recommendations and consumer reviews in ecommerce transactions: an experimental study, Journal of Management Information Systems, vol. 29, no. 1, pp. 237-272, 2012.

[8] L. Blasco-Arcas, B. Hernandez-Ortega and J. Jimenez-Martinez, Adopting television as a new channel for ecommerce. The influence of interactive technologies on consumer behavior, Electronic Commerce Research, vol. 13, no. 4, pp. 457-475, 2013.

[9] S. A. Brown and V. Venkatesh, Model of adoption on technology in households: A baseline model test and extension incorporating household life cycle, MIS Quarterly, vol. 29, no. 3, pp. 399-426, 2005.

[10] M. Brucks, The effects of product class knowledge on information search behavior, Journal of Consumer Research, vol. 12, no. 1, pp. 1-15, 1985.

[11] E. Brynjolfsson, Y. Hu and M. Smith, Consumer surplus in the digital economy: Estimating the value of increased product variety, Management Science, vol. 49, no. 11, pp. 1580-1596, 2003.

[12] A. Burton-Jones and D. W. Straub, Reconceptualizing system usage: An approach and empirical test, Information System Research, vol. 17, no. 3, pp. 228-246, 2006.

[13] M. Chang, W. Cheung and S. Lai, Literature derived reference models for the adoption of online shopping, Information \& Management, vol. 42, no. 4, pp. 543-559, 2005.

[14] M. Chen and C. Teng, A comprehensive model of the effects of online store image on purchase intention in an e-commerce environment, Electronic Commerce Research, vol. 13, no. 1, pp. 1-23, 2013.

[15] J. V. Chen, D. C. Yen and K. Chen, The acceptance and diffusion of the innovative smart phone use: A case study of a delivery service company in logistics, Information \& Management, vol. 46, no. 4, pp. 241-248, 2009.

[16] J. Cho, Likelihood to abort an online transaction: Influence from cognitive evaluations, attributes, and behavioral variables, Information \& Management, vol. 41, no. 7, pp. 827-838, 2004.

[17] V. Choudhury and E. Karahanna, The relative advantage of electronic channels: A multidimensional view, MIS Quarterly, vol. 32, no. 1, pp. 179-200, 2008.

[18] C. Comegys, M. Hannula and J. Vaisanen, Longitudinal comparison of finish and us online shopping behavior among university students: The five-stage buying decision process, Journal of Targeting, Measurement and Analysis for Marketing, vol. 14, no. 4, pp. 336-356, 2006.

[19] M. D. Coomes and R. Debard, Serving the Millennial Generation: New Directions for Student Services, Number 106. San Francisco, CA: Jossey-Bass, 2004.

[20] D. Cyr, Modeling web site design across cultures: Relationships to trust, satisfaction, and e-loyalty, Journal of Management Information Systems, vol. 24, no. 4, pp. 47-72, 2008.

[21] F. D. Davis, Perceived usefulness, perceived ease of use, and user acceptance of information technology, MIS Quarterly, vol. 13, no. 3, pp. 319-340, 1989.

[22] F. D. Davis, R. P. Bagozzi and P. R. Warshaw, User acceptance of computer technology: A comparison of two theoretical models, Management Science, vol. 35, no. 8, pp. 982-1003, 1989. 
[23] C. Dellarocas, G. Gao and R. Narayan, Are consumers more likely to contribute online reviews for hit or niche products?, Journal of Management Information Systems, vol. 27, no. 2, pp. 127-157, 2010.

[24] U. Dholakia and L. Rego, What makes commercial web pages popular?: An empirical investigation of web page effectiveness, European Journal of Marketing, vol. 3, no. 7/8, pp. 724-736, 1998.

[25] C. Elam, T. Stratton and D. D. Gibson, Welcoming a new generation to college: The millennial students, Journal of College Admission, vol. 195, pp. 20-25, 2007.

[26] R. R. Evans and L. Forbes, Mentoring the net generation: Faculty perspectives in health education, College Student Journal, vol. 46, no. 2, pp. 397-404, 2012.

[27] A. Everard and F. Galletta, How presentation flaws affect perceived site quality, trust, and intention to purchase from an online store, Journal of Management Information Systems, vol. 22, no. 3, pp. 55-95, 2006.

[28] A. M. Fiore, H.J. Jin and J. Kim, For fun and profit: Hedonic value from image interactivity and responses toward an online store, Psychology \& Marketing, vol. 22, no. 8, pp. 669-694, 2005.

[29] A. Flanagin, M. Metzger, R. Pure, A. Markov, and E. Hartsell, Mitigating risk in ecommerce transactions: Perceptions of information credibility and the role of user-generated rating in product quality and purchase intention, Electronic Commerce Research, vol. 14, no. 1, pp. 1-23, 2014.

[30] E. Garbarino and F. Lee, Dynamic pricing in internet retail: Effects on consumer trust, Psychology \& Marketing, vol. 20, no. 6, pp. 495-513, 2003

[31] M. Giurgiulescu, G. Pânişoară, I. O. Pânişoară, and C. M. Sandu, Ways to develop a positive attitude of students -digital natives - to reduce disaster risks, Advances in Environmental Sciences- International Journal of the Bioflux Society, vol. 7, no. 2, pp. 230-239, 2015.

[32] D. Gefen, E. E. Rigdon and D. Straub, An update and extension to SEM guideline for administrative and social science research, MIS Quarterly, vol. 35, no. 2, pp. 3-14, 2011.

[33] D. L. Goodhue, W. Lewis and R. Thompson, Does PLS have advantages for small sample size or non-normal data? MIS Quarterly, vol. 36, no. 3, pp. 981-1001, 2012.

[34] D. L. Goodhue, W. Lewis and R. Thompson, Comparing PLS to regression and LISREL: A response to Marcoulides, Chin, and Saunders, MIS Quarterly, vol. 36, no. 3, pp. 703-716, 2012.

[35] J. F. Hair, G. T. M. Hult, C. M. Ringle, and M. Sarstedt, A Primer on Partial Least Squares Structural Equation Modeling (PLS-SEM). Thousand Oaks, CA: Sage, 2014.

[36] O. Hinz Hann and M. Spann, Price discrimination in e-commerce? An examination of dynamic pricing in nameyour-own price markets, MIS Quarterly, vol. 35, no. 1, pp. 81-98, 2011.

[37] D. P. Horan, Digital natives and the digital self: The wisdom of Thomas Merton for millennial spirituality and selfunderstanding, The Merton Annual, vol. 24, pp. 83-111, 2011.

[38] N. Howe and W. Strauss, Millennials Rising: The Nest Great Generation. New York, NY: Vintage Books, 2000.

[39] J. Hsieh, A. Rai and M. Keil, Understanding digital inequality: comparing continued use behavioral models of the socio-economically advantaged and disadvantaged, MIS Quarterly, vol. 32, no. 1, pp. 97-126, 2008.

[40] S. Jarvenpaa and A. Todd, Consumer reactions to electronic shopping on the world wide web, International Journal of Electronic Commerce, vol. 1, no. 2, pp. 59-88, 1996-1997.

[41] J. Jahng, H. Jain and K. Ramamurthy, Effects of interaction richness on consumer attitudes and behavioral intentions in e-commerce: Some experimental results, European Journal of Information Systems, vol. 16, no. 3, pp. 254-269, 2007.

[42] P. Ji and P. S. Lieber, Am I safe? Exploring relationships between primary territories and online privacy, Journal of Internet Commerce, vol. 9, no. 1, pp. 3-22, 2012.

[43] C. Jones and S. J. Cross, Is there a net generation coming to university? in Proceedings of 16th International Conference of the Association for Learning Technology, Manchester, UK. 2009, pp. 10-20.

[44] C. Jones and G. Healing, Net generation students: Agency and choice and the new technologies, Journal of Computer Assisted Learning, vol. 26, no. 5, pp. 344-356, 2010.

[45] C. Jones, R. Ramanau, S. Cross, and G. Healing, Net generation or digital natives: Is there a distinct new generation entering university? Computers \& Education, vol. 54, no. 3, pp. 722-732, 2010.

[46] A. C. Johnston, M. Warkentin and M. Siponen, An enhanced fear appeal rhetorical framework: Leveraging threats to the human asset through sanctioning rhetoric, MIS Quarterly, vol. 39, no. 1, pp. 113-134, 2015.

[47] C. Junginger, Who Is training whom? The effect of the millennial generation, FBI Law Enforcement Bulletin, vol. 77, no. 9, pp. 19-23, 2008.

[48] R. Keeney, The value of internet commerce to the customer, Management Science, vol. 45, no. 4, pp. 533-542, 1999.

[49] G. Kennedy, T. Judd, B. Dalgarno and J. Waycott, Beyond natives and immigrants: Exploring types of net generation students, Journal of Computer Assisted Learning, vol. 26, no. 5, pp. 332-343, 2010

[50] M. Khalifa and V. Liu, Online consumer retention: Contingent effects of Online Shopping Habit and online hopping experience, European Journal of Information Systems, vol. 16, no. 6, pp. 780-792, 2007.

[51] J. Kim and J. Lee, Critical design factors for successful e-commerce systems, Behavior \& Information Technology vol. 21, no. 3, pp. 185-199, 2002.

[52] D. Kim and I. Benbasat, Trust-related arguments in Internet stores: A framework for evaluation, Journal of Electronic Commerce Research, vol. 4, no. 2, pp. 49-64, 2003.

[53] J. Kim, N. Spielmann and S. J. McMillan, Experience effects on interactivity: Functions, processes, and perceptions, Journal of Business Research, vol. 65, no. 11, pp. 1543-1550, 2012.

[54] J. B. Kim, An Empirical study on consumer first purchase intention in online shopping: Integrating initial trust and TAM, Electronic Commerce Research, vol. 12, no. 2, pp. 125-150, 2012. 
[55] C. P. Kirk, L. Chiagouris, V. Lala and J.D.E. Thomas, How do digital natives and digital immigrants respond differently to interactivity online? A model for predicting consumer attitudes and intentions to use digital information products, Journal of Advertising Research, vol. 51, no. 1, pp. 81-94, 2015.

[56] M. Koufaris, Applying technology acceptance model and flow theory to online consumer behavior, Information Systems Research, vol. 13, no. 2, pp. 205-223, 2002.

[57] R. Kumar, A. Smith and S. Bannerjee, User interface features influencing overall ease of use and personalization, Information \& Management, vol. 41, no. 3, pp. 289-302, 2004

[58] L. C. Lancaster and D. Stillman, When generations collide. New York, NY: HarperCollins Publishers Inc, 2002.

[59] G. Laurent and J. Kapfere, Measuring consumer involvement profiles, Journal of Marketing Research, vol. 22 , no. 1, pp. 41-53, 1985.

[60] L. Leung, Net-generation attributes and seductive properties of the internet as predictors of online activities and internet addition, Cyber Psychology \& Behavior, vol. 7, no. 3, pp. 333-348, 2004.

[61] C. Lopez-Nicolas, F. J. Molina-Castillo and H. Bouwman, An assessment of advanced mobile services acceptance: Contributions from TAM and diffusion theory models, Information \& Management, vol. 45, no. 6, 359-364, 2008

[62] C. Lopez-Nicolas and F. J. Molina-Castillo, Customer knowledge management and e-commerce: The role of customer perceived risk, International Journal of Information Management, vol. 28, no. 2, pp. 102-113, 2008.

[63] J. Luo, S. Ba and H. Zhang, The effectiveness of online shopping characteristics and well-designed websites on satisfaction, MIS Quarterly, vol. 36, no. 4, pp. 1131-1144, 2012.

[64] A. McAlister, Teaching the millennial generation, American Music Teacher, vol. 59, no. 1, pp. 13-15, 2009.

[65] C. Mcmellon, L. Schiffman and E. Sherman, Consuming cyberseniors: Some personal and situational characteristics that influence their on-line behavior, Advances in Consumer Research, vol. 24, no. 1, pp. 517521,1997

[66] C. Mcmellon and L. Schiffman, Cybersenior mobility: Why some older consumers may be adopting the internet, Advances in Consumer Research, vol. 27, no. 1, pp. 139-144, 2000.

[67] C. Mcmellon and L. Schiffman, Cybersenior empowerment: how some older individuals are taking control of their lives, The Journal of Applied Gerontology, vol. 21, no. 2, pp. 157-175, 2002.

[68] A. Merle, S. Senecal and A. St-Onge, Whether and how virtual try-on influences consumer responses to an apparel web site, International Journal of Electronic Commerce, vol. 16, no. 3, pp. 41-64, 2012

[69] N. Miyake and D. Norman, To ask a question, one must know enough to know what is not known, Journal of Verbal Learning and verbal Behavior, vol. 18, no. 3, pp. 357-364, 1979.

[70] S. Moorthy, B. Ratchford and D. Talukdar, Consumer information search revisited: Theory and empirical analysis, Journal of Consumer Research, vol. 23, no. 4, pp. 263-277, 1997.

[71] B. Murthi and S. Sarkar, The role of the management sciences in research on personalization, Management Science, vol. 49, no. 10, pp. 1344-1362, 2003.

[72] J. Napoli and M. Ewing, The net generation: An analysis of lifestyles, attitudes and media habits, Journal of International Consumer Marketing, vol. 13, no. 1, pp. 21-34, 2001

[73] D. Oblinger and J. Oblinger, Educating the Net Generation. Washington: EDUCAUSE press, 2005.

[74] R. Olbrich and C. Holsing, Modeling consumer purchasing behavior in social shopping communities with clickstream data, International Journal of Electronic Commerce, vol. 16, no. 2, pp. 15-40, 2011-2012.

[75] J. Palfrey and U. Gasser, Born Digital: Understanding the First Generation of Digital Natives. New York, NY: Basic Books, 2008.

[76] J. Palmer, Web site usability, design, and performance metrics, Information Systems Research, vol. 13, no. 2, pp. 151-167, 2002.

[77] T. Papaioannou and G. Stamoulis, A mechanism that provides incentives for truthful feedback in peer-to-peer systems, Electronic Commerce Research, vol. 10, no. 3, pp. 331-362, 2010

[78] B. Pathak, R, Garfinkel, R. Gopal, R. Venkatesan, and F. Yin, Empirical analysis of the impact of recommender systems on sales, Journal of Management Information Systems, vol. 27, no. 2, pp. 159-188, 2010.

[79] S. Park and E. Lee, Net generation: The growing dominant consumer group in network society, Asia Pacific Advances in Consumer Research, vol. 6, no. 1, pp. 239-243, 2005.

[80] P. Pavlou and M. Fygenson, Understanding and predicting electronic commerce adoption: An extension of the theory of planned behavior, MIS Qualiterly, vol. 30, no. 1, pp. 115-143, 2006.

[81] P. Pavlou, H. Liang and Y. Xue, Understand and mitigating uncertainty in online exchange relationships: A principal-agent perspective, MIS Quarterly, vol. 31, no. 1, pp. 105-136, 2007.

[82] C. Phang, A. Kankanhalli, K. Ramakrishnan, and K. Ramen, Customers' preference of online store visit strategies: An investigation of demographic variables, European Journal of Information Systems, vol. 19, no. 3, pp. 344-358, 2010.

[83] C. Posey, P. Lowry, T. Roberts and T. Ellis, Proposing the online community self-disclosure model: The case of working professionals in France and the U.K. who use online communities? European Journal of Information Systems, vol. 19, no. 2, pp. 181-195, 2010.

[84] M. Prensky, Digital natives, digital immigrants, The Horizon, vol. 9, no. 5, pp. 1-6, 2001.

[85] G. Punj and R. Staelin, A model of consumer information search behavior for new automobiles, Journal of Consumer Research, vol. 9, no. 4, pp. 366-380, 1983.

[86] I. Qureshi, Y. Fang, E. Ramsey, P. Mccole, P. Ibbotson, and D. Compeau, Understanding online customer repurchasing intention and the mediating role of trust - an empirical investigation in two developed countries, European Journal of Information Systems, vol. 18, no. 3, pp. 205-222, 2009. 
[87] R. Ramanathan, E-commerce success criteria: Determining which criteria count most, Electronic Commerce Research, vol. 10, no. 2, pp. 191-208, 2010.

[88] R. Riedl, M. Hubert and P. Kenning, Are there neural gender differences in online trust? An MRI study on the perceived trustworthiness of ebay offers, MIS Quarterly, vol. 34, no. 2, pp. 397-428, 2010.

[89] C. M. Ringle, M. Sarstedt and D. W. Sraub, A Critical look at the use of PLS-SEM in MIS Quarterly, MIS Quarterly, vol. 36, no. 1, pp. 3-14, 2012.

[90] F. D. Salajan, D. J. Schonwetter and B. M. Cleghorn, Student and faculty inter-generational digital divide: Fact or fiction, Computers \& Education, vol. 55, no. 3, pp. 1393-1403, 2010.

[91] D. Selz and P. Schubert, Web assessment- a model for the evaluation and the assessment of successful electronic commerce applications, Electronic Markets, vol. 7, no. 3, pp. 46-48, 1997.

[92] M. Sheppard and C. Vibert, Cases for the net generation: An empirical examination of students' attitude toward multimedia case studies, Journal of Education for Business, vol. 91, no. 2, pp. 101-107, 2016.

[93] G. Shergill and Z. Chen, Web-based shopping: consumers' attitudes towards online shopping in New Zealand, Journal of Electronic Commerce Research, vol. 6, no. 2, pp. 79-94, 2005.

[94] M. D. Sotiriadis and C. V. Zyl, Electronic word-of-mouth and online reviews in tourism services: The use of twitter by tourists, Electronic Commerce Research, vol. 13, no. 1, pp. 103-124, 2013.

[95] K. Srikumar and B. Bhasker, Personalization product selection in internet business, Journal of Electronic Commerce Research, vol. 5, no. 4, pp. 216-227, 2004.

[96] B. Suh and I. Han, The impact of customer trust and perception of security control on the acceptance of electronic commerce, International Journal of Electronic Commerce, vol. 7, no. 3, pp. 135-161, 2003.

[97] K. Tam and S. Ho, Web personalization as a persuasion strategy: an elaboration likelihood model perspective, Information Systems Research, vol. 16, no. 3, pp. 271-291, 2005.

[98] D. Tapscott, Grown up digital: how the Net generation is changing your world. New York, NY: McGraw-Hill, 2008.

[99] E. Thomson and A. Laing, The net generation: Children and young people, the internet and online shopping, Journal of Marketing Management, vol. 19, no. 3-4, pp. 91-512, 2003.

[100] G. Torkzadeh and G. Dhillon, Measuring factors that influence the success of internet commerce, Information Systems Research, vol. 13, no. 2, pp. 187-204, 2002.

[101] $\mathrm{H}$. Tsai and $\mathrm{H}$. Heung-Chinang, Determine of e-repurchase intentions: an integrative model of quadruple retention drivers, Information \& Management, vol. 44, no. 3, pp. 231-239, 2007.

[102] L. L.Tung, Y. Xu and F. B. Tan, Attributes of web site usability: A study of web users with the repertory grid technique, International Journal of Electronic Commerce, vol. 13, no. 4, pp. 97-126, 2009.

[103] G. Udo and G. Marquis, Factors affecting e-commerce web site effectiveness, Journal of Computer Information Systems, vol. 42, no. 2, pp. 10-16, 2001/2002.

[104]H. Van Der Heijden, T. Verhagen and M. Creemers, Understanding online purchase intentions: Contributions from technology and trust perspectives, European Journal of Information Systems, vol. 12, no. 1, pp. 41-48, 2003.

[105] V. Venkatesh, S. A. Brown, L. M. Maruping, and H. Bala, Predicting different conceptualizations of system use: The competing roles of behavioral intention, facilitating conditions, and behavioral expectation, MIS Quarterly, vol. 32, no. 3, pp. 483-502, 2007.

[106] V. Venkatesh and F. D. Davis, A theoretical extension of the technology acceptance model: Four longitudinal field studies, Management Science, vol. 46, no. 2, pp. 186-204, 2000.

[107] V. Venkatesh, M. G. Morris, G. B. Davis and F. D. Davis, User acceptance of information technology: Toward a unified view, MIS Quarterly, vol. 27, no. 3, pp. 425-478, 2003.

[108] V. Venkatesh, J. Y. L.Thong and X. Xu, Consumer acceptance and use of information technology: Extending the unified theory of acceptance and use of technology, MIS Quarterly, vol. 36, no. 1, pp. 157-178, 2014

[109] L. Vijayasarathy, Predicting consumer intentions to use on-line shopping: the case for an augmented technology acceptance model, Information \& Management, vol. 41, no. 6, pp. 747-762, 2003.

[110] S. K. Wang, H. Y. Hsu, T. Campbell, D. C. Coster, and M. Longhurst, An investigation of middle school science teachers and students use of technology inside and outside of classrooms: Considering whether digital natives are more technology savvy than their teachers, Education Technology Research \& Development, vol. 62, no. 6, pp. 637-662, 2014.

[111]J. D. Wells, J. S. Valacich and T. J. Hess, What signal are you sending? How website quality influences perceptions of product quality and purchase intentions, MIS Quarterly, vol. 35, no. 2, pp. 373-396, 2011.

[112]M. Wolfinbarger and M. Gilly, eTailQ: Dimensionalizing, measuring and predicting e-tail quality, Journal of Retailing, vol. 79, no. 3, pp. 183-198, 2003.

[113] K. Worley, Educating college students of the net generation, Adult Learning, vol. 22, no. 3, pp. 31-39, 2011

[114] J. Xu, I. Benbasat and R. T. Cenfetelli, Integrating service quality with system and information quality: An empirical test in the e-service context, MIS Quarterly, vol. 37, no. 4, pp. 1043-1068, 2013.

[115]T. Zhang, R. Agarwal and $H$. Lucas, The value of it-enabled retailer learning: Personalized product recommendations and customer store loyalty in electronic markets, MIS Quarterly, vol. 35, no. 4, pp. 859-881, 2011 